\title{
A Pure Bureaucratic-Entrepreneurial Theory of Deposit Insurance Adoption
}

\author{
KAM HON CHU \\ Memorial University of Newfoundland *
}

\begin{abstract}
Based on Becker, Kane, Niskanen, and Peltzman's ideas, we develop a model to explain why deposit insurance is adopted even though policymakers are aware of its pitfalls in both theory and practice. In our model, the regulator acts as both a bureaucrat and an entrepreneur to maximize his self-interest through administering a deposit insurance scheme. The theory postulates that adoption of deposit insurance is more likely under the following conditions: the scheme is (i) publicly administered and (ii) privately funded, with (iii) non-risk rated insurance premium and (iv) compulsory membership; and there is (v) a larger deposit market with (vi) at least two groups of banks (good vs. bad), (vii) lower government ownership of banks, and (viii) higher economic freedom, such that one group exerts its political influence and gains from deposit insurance. Empirically our theory is supported by the stylized facts, cross-country binary-choice regression results and a case study of Canada.
\end{abstract}

Keywords: Bureaucracy, Canada, Deposit Insurance, Economic Regulation, Political Economy, Private Interest Theory of Regulation, Public Interest Theory

JEL Classifications: G21, G28, K23, L51

\begin{abstract}
* Department of Economics, kchu@mun.ca. This is a revised and substantially extended version of my paper entitled "A Bureaucratic-Entrepreneurial Theory of Deposit Insurance" presented to the Faculty of Law, Chinese University of Hong Kong, at its 10th Anniversary Conference on the Political Economy of Financial Regulation. I would like to thank Kartik Anand, Christian Chamorro-Courtland, Xi Chao, Maria Gallego, Edward Kane, Hai Nguyen, Sam Peltzman, Derek Pyne, Ad van Riet, Zhengyi Zhou and also participants at the conference for their comments and suggestions. In particular, I am grateful to Edward Kane, Sam Peltzman, and three anonymous referees for their valuable comments and suggestions, which definitely improve the quality of this paper. All remaining errors are, however, my own. Part of this research was carried out when the author visited the School of Economics and Finance, the University of Hong Kong, during January-May 2016. I am very grateful for the hospitality of the faculty and staff of the School, notably Drs. Alex Chan Wing-Ho, Stephen Chui Yiu-Wah, Paul Lau Sau-Him, Chung-Yi Tse, and Ka-Fu Wong. Last but not least, I am intellectually indebted to Jack Carr, whose teachings remain despite his retirement.
\end{abstract}

(C) 2021 Kam Hon Chu. Licensed under the Creative Commons Attribution - Noncommercial 4.0 Licence (http: / / creativecommons.org/licenses/by-nc/4.0/. Available at http: //rofea.org. 


\section{Introduction}

Despite the notorious moral hazard problem and recurrence of banking crises associated with explicit deposit insurance schemes (hereafter EDIS), there has been a global trend of instituting EDIS since the 1980s (World Bank 2001). Interestingly, this trend remains largely unexplained and Demirgüç-Kunt and Detragiache (2002) attribute it to "fads." Later, Demirgüç-Kunt et al. (2008) empirically found that external political pressure from the IMF, World Bank, and European Union, emulation of other countries, experience with financial crisis, democratic political process, GDP per capita and inflation are significant determinants of EDIS adoption.

It is well known that the first nation-wide deposit insurance scheme was set up by the US Federal Deposit Insurance Corporation (FDIC) in 1934; so if EDIS were effective in maintaining banking stability, other countries would have followed suit shortly. But in fact the US savings and loan debacle of the 1980s (e.g. Kane 1989, Barth 1991) and similar mishaps in other countries, like Canada (Carr et al. 1994, 1995) have revealed the huge costs and inefficiency of EDIS. Demirgüç-Kunt and Detragiache (2002) empirically show that EDIS work only among countries with strong institutional settings such as strong regulation, rules of law, etc. ${ }^{1}$ Among the ample evidence indicating that EDIS are no panacea for banking stability, Chu (2003) shows that EDIS have a short-run stabilizing effect but a long-run destabilizing effect, and later (Chu 2011) also finds that the higher the deposit insurance coverage, the more severe the banking crisis. Therefore, the destabilizing effect and costs should have discouraged countries from adopting EDIS.

So why did policymakers still jump on the bandwagon in adopting EDIS? ${ }^{2}$ Some countries had implicit deposit insurance such that depositors did not suffer any loss in bank failures; then why did they later set up EDIS? Were regulators poorly informed about the performance of EDIS? Were they simply irrational? Or were there other possible reasons?

As will be seen in Section 2, the public-interest theories do not explain EDIS adoption satisfactorily or they are inconsistent with the facts in one way or another. Consequently some scholars have rejected the public-interest arguments and postulated that EDIS are the outcome of private interest instead. ${ }^{3}$

\footnotetext{
${ }^{1}$ See also Demirgüç-Kunt and Kane (2002) for details.

${ }^{2}$ Engineer et al. (2013) offer an alternative explanation based on a non-cooperative policy game model: nations compete for deposits in order to protect their banking systems from the destabilizing impact of potential capital flight. Their explanation and ours are not mutually exclusive, however.

${ }^{3}$ The notion that regulators do not necessarily serve the public interest but rather the interests of the political regulators and pressure groups has a long history. See, for example, the pioneer works of Stigler (1971), Peltzman (1976), and Becker (1983), to name just a few. The later studies (e.g. Kane 1990) can be regarded as extensions and applications of these pioneer works to banking regulation.
} 


\section{KAM HON CHU Theory of Deposit Insurance Adoption}

Based on a private-interest argument, this paper offers a bureaucratic-entrepreneurial theory of EDIS adoption. In a nutshell, it postulates that regulators, like ordinary economic agents, maximize their own self-interest and have incentives to introduce EDIS if they can derive benefits, say, higher salaries, more fringe benefits, higher office expenses, etc., (e.g. Niskanen 1971) that outweigh the costs of more input efforts in administering EDIS and in regulating banks, etc. On the one hand, regulators are bureaucrats. But on the other hand, they are also entrepreneurs who have incentives to seek their benefits or profit opportunities by building their own enterprises - EDIS in this case. From an alternative perspective, regulators with their regulatory power and as rent seekers put forward EDIS as rent extraction so as to threaten and force banks to cede and share part of their interests with the regulators.

Our theory postulates that EDIS adoption is more likely under the following conditions: the scheme is (i) publicly administered and (ii) privately funded, with (iii) non-risk rated insurance premium and (iv) compulsory membership; and there is (v) a larger deposit market with (vi) at least two groups of banks (good vs. bad), (vii) lower government ownership of banks, and (viii) higher economic freedom.

Empirically we test our theory based on cross-country data for the year 2013 released by the World Bank and other data sources. Adoption of an EDIS is modeled as a binary-choice dependent variable with explanatory variables (or proxies) derived or inferred from our theory and other control variables as determinants. As in previous empirical studies, our regression results indicate that banking crises and political factors are significant determinants of EDIS adoption. Consistent with the predictions of our theory, the results suggest that, all other things equal, EDIS adoption is more likely with a higher ratio of deposits to GDP (or deposits-GDP ratio hereafter), a lower five-firm concentration ratio in the banking industry and a lower government ownership of banks.

Recognizing the limitations of the regression analysis, we also carry out statistical analysis to compare economies with and without EDIS, and examine Canada's introduction of Canadian Deposit Insurance Corporation (CDIC) in 1967 as a case study. In sum, results of the statistical and regression analyses and of the case study lend support to our theory.

This paper is organized as follows. The next section elaborates on the inadequacy of publicinterest theories in explaining the trend of EDIS adoption and thus motivates our theory. Section 3 offers a brief literature review, followed by the theoretical model and its empirical implications. The data, empirical methods and findings are discussed in Section 5. We examine the Canadian experience as a case study in the penultimate section before the paper concludes. 


\section{Inadequacy of Public-Interest Theories in Explaining EDIS Adoption}

Besides the huge costs and ineffectiveness of EDIS, it is also puzzling when we try to reconcile the trend of EDIS with the theories justifying deposit insurance or theories of economic agents' behavior towards risk. More specifically, almost all industrial countries have instituted EDIS. By contrast, EDIS are less common in emerging markets and less developed countries (LDCs), even though there is a growing trend of adoption among the former. Why is there such a systematic pattern?

There may be several possible explanations for this phenomenon. First, one may argue that only industrial countries can afford EDIS because they are costly to set up. But this explanation is unsatisfactory. Even though the costs of EDIS are high in the long run because of bank failures associated with moral hazard problems (e.g. Barth 1989, Barth et al. 1991), the initial setup costs require relatively low outlays from the stakeholders.

Furthermore, financial regulation is generally more complex and extensive in industrial countries than in LDCs. If banking regulation was effective in maintaining banking stability, then why did industrial countries further institute costly EDIS? At the margin, the benefits from introducing EDIS may not outweigh the costs in the long run.

Superficially, the rise of EDIS in developed countries may be resulted from wealthy people's demand because the rich is more inclined than the poor to take risk and to insure themselves simultaneously. However, wealthy investors typically hold diversified risky portfolios more than safe assets like deposits. Moreover, financial markets in developed countries are more efficient and more innovative than in LDCs such that wealthy investors are able, to some extent, to self-insure by holding well-diversified portfolios with low transaction costs. Furthermore, if regulators follow a too-big-to-fail policy, then wealthy investors who hold mega-bank shares can even enjoy the subsidies from implicit deposit insurance of such a policy, not to mention that they can politically influence the payouts. ${ }^{4}$ To them, the benefit of EDIS is marginal, if not redundant, as their portfolios are largely uncovered by EDIS. As financial safety nets, therefore, EDIS should be relatively more popular in countries where financial markets are less well-developed. However, this argument is simply counterfactual and inconsistent with one of the "stylized facts" of EDIS. ${ }^{5}$

\footnotetext{
${ }^{4}$ I am indebted to Professor Kane for pointing out this possible scenario to me.

${ }^{5}$ The "stylized facts" of EDIS are the following typical observations (though there are few exceptions in each case): (i) EDIS are mostly found in developed and high-income countries, whereas most LDCs do not have EDIS; (ii) EDIS membership is typically compulsory; (iii) foreign currency deposits are usually uncovered; (iv) EDIS are commonly funded from private banks' resources; (v) EDIS are typically managed by government agencies; (vi) premiums are typically based on amount of insured bank deposits rather than bank risk; and (vii) co-insurance provisions are rare. This list may not be exhaustive. For more details, see Dermirgüç-Kunt et al. (2008, 2014, and 2015).
} 


\section{KAM HON CHU Theory of Deposit Insurance Adoption}

One may then argue that an objective of EDIS is to protect small depositors rather than wealthy investors. If so, with less developed welfare systems, or even in their absence, LDCs should have higher incentives to adopt EDIS than developed countries because the adverse impact of deposit losses on small depositors is, at the margin, higher than on large depositors. This publicinterest argument is again counterfactual.

To support the public-interest argument, one may further argue that most developed countries are democratic and, as outcomes of democratic political processes, their governments are elected to protect the majority of their citizens by introducing EDIS. As far as we know, however, none of the existing EDIS was introduced as a result of referendum or as an important issue in a political plank and platform during an election campaign. In almost all cases, governments simply introduced EDIS in a top-down manner, at most with some consultations. One striking feature in the European EDIS was that "the public is totally ignorant of their existence. Publicity is even forbidden in the Federal Republic of Germany" (Baltensperger and Dermine 1990, p.28). Following the EU Directive on Deposit Guarantee Schemes of 1994, EDIS adoption is an obligation of EU membership rather than a choice (Huizinga 2008). Apparently, democracy has not been a decisive driving force. Ironically, a benevolent altruistic dictator, say, in a LDC, would have set up an EDIS to protect poor small depositors if his objective was really to promote public interest.

This is not to say that democracy plays no role at all in the process of EDIS adoption. A democracy tends to allow different interest groups to influence government's decisions than does a non-democracy (e.g. Demirgüç-Kunt et al. 2008). But it is almost practically impossible that these special interests coincide exactly with the public interest, not to mention that regulators have their own career interests (Kane 1990).

Arguably, a main public-interest argument for EDIS is its efficacy in preventing bank runs. But bank runs are not necessarily contagious and they can in effect maintain strong market discipline (e.g. Kaufman 1994, 1996). On the other hand, the public-interest argument based on protection of small depositors cannot adequately justify the need of EDIS because there are less costly alternatives to achieve this goal, such as short-term treasury securities (Benston and Kaufman 1988), checkable money market mutual funds (Cowen and Kroszner 1990), and government saving bonds (Chu 2000), to mention just a few.

\section{A Brief Literature Review}

\subsection{Public-interest versus Private-interest Theories}

It is not quite possible to give a review of the extensive literatures on banking regulation, deposit insurance and economics of regulation. To make the task manageable, we focus on the major studies more relevant to this study so as to facilitate the reader to have a better understanding 
of the issues involved. We begin with the political economy theories of regulation in general and then review how they have been applied to banking regulation and to EDIS adoption in particular.

Historically, theories of economic regulation have mainly focused on regulation of industries like public utilities (e.g. Kahn 1989[1970/71]) rather than banking until recently. Traditionally, regulation has been justified based on the public-interest theory, i.e., regulation is a public policy that addresses the private sector's behaviors so as to promote the general public's welfare (e.g. Mitnick 1980). One major shortcoming of the public-interest theory is its inconsistency with empirical evidence or stylized facts. The theory asserts that government regulation arises in response to the public's demand for correcting inequitable practices or market failures due to natural monopoly, externalities, asymmetric information, etc. But Viscount et al. (2005, pp. 375-80) criticize it being a hypothesis or statement about empirical regularities rather than a theory. Both theoretical and empirical studies have demonstrated that regulation is not positively correlated with existence of externalities or monopoly (Posner 1974). Instead, the empirical evidence tends to support that regulation is in favor of producers rather than consumers.

This empirical evidence saw the development of one of the most well-known theories against the public-interest theory, namely the capture theory according to which, instead of promoting public interest, the regulator is captured by the regulated industry to supply regulation so as to promote the latter's interest, or the regulator is captured by the regulated industry over time (e.g. the life cycle model of Chatov 1978). Although the capture theory has more empirical support and is more consistent with the regulatory history than the publicinterest theory, it is criticized for its lack of a theoretical foundation and its contradiction to certain empirical evidence (e.g. Posner 1975, Viscount et al. 2005, among others). Nevertheless, it has highlighted the main notion that regulation is based on private rather than public interest.

Since the early 1970s, several private-interest theories of regulation have been put forward. A path-breaking approach is the economic theory of regulation by Stigler (1971) who criticizes the public-interest theory on several grounds. First, the concept of public interest is vague because an economic policy can be beneficial to one interest group but harmful to another. Second, it is difficult to find empirical evidence to support the public-interest theory. Third, there can be divergence between the regulator's objective and that of the regulated. Based on the simple notion of demand and supply, Stigler argues that demand for regulation arises from certain interest groups in an industry whereas the supply comes from regulators or politicians; regulation is a means through which wealth is transferred from one interest group to another. His theory admits the possibility of capture of the regulator by interest groups, but it replaces the capture metaphor by the neutral terminology of demand and supply. 


\section{KAM HON CHU Theory of Deposit Insurance Adoption}

Peltzman (1976) extends Stigler's model by putting forward a political support function to explain which industries are more likely to be regulated. The regulator chooses the form of regulation, such as price regulation, to maximize the political support from the majority. Similar to Stigler's theory, the regulator transfers wealth from one interest group to another in the process of seeking political support. Along a similar line of argument, Becker (1983) develops a model in which two interest groups compete with each other in influencing the regulator in order to maximize their own welfare. Other theories built upon Stigler's theory of economic regulation include the Posner's (1975) cartel model of regulation and Hettich and Winer's (1988) tax structure model, to name just a few.

Another strand of literature on private-interest theories of regulation is based on the seminal idea of rent seeking pioneered by Tullock (1967) and Krueger (1974). Rent seeking is a nonproductive activity that protects the vested interest groups or redistributes wealth from one interest group to another. In the arena of regulation, McChesney (1987) proposes the concepts of political rent creation and rent extraction. In political rent creation, government officials or politicians can use their political or regulatory power to intervene and to increase the profits of certain private businesses; in return, the private businesses will share the increased profits with them. In rent extraction, regulators or politicians deliberately propose a certain policy that can harm some private businesses so as to threaten the latter to cede and share part of their interests with the politicians.

\subsection{Applications to Banking}

Needless to say, politics and banking interact and how the political game played by politicians, bankers, and various interest groups explains why banking varies dramatically across countries (Calomiris and Haber 2014). The notion of public interest has been extended to banking or financial regulation, including deposit insurance. In a highly influential paper, Diamond and Dybvig (1983) develop a theoretical model in which a bank run can be characterized as a "bad" equilibrium that leads to deterioration in depositors' welfare, thus justifying EDIS adoption to promote banking stability. On the other hand, Friedman and Schwartz (1986) provide economic arguments to justify the role of government in money and banking; one argument is that bank runs or banking panics have negative externalities on the economy. In brief, there are economic reasons to justify EDIS based on public interest.

In contrast, the private-interest views of regulation of industries have been extended to banking regulation in the last two decades. To understand the emergence of financial regulation, as correctly pointed out by Roe (1990), it is crucial to understand the behaviors of the government and politicians from a political economy perspective. In fact, politicians do not necessarily act only as representatives for the public interest because they themselves have their own interests. This view has been echoed by Boot and Thakor (1993) and Kane (1990), among 
others. More formally, Kroszner and Stratmann (1998) provide evidence of competition among interest groups to increase their franchise value in the US financial services industry, followed by Kroszner and Strahan $(1999,2001)$ who argue that US banking policies are primarily shaped by the private interests of the regulators and the regulated rather than by public interest. More specifically, they note that smaller US banks used their dominant position and political influence to delay branching deregulation and that the timing of bank deregulation reflected not only industry development but also the different interest groups' relative power. Similarly, Shleifer and Vishny (1998) and La Porta et al. (2002) argue that governments regulate banks to promote political constituencies. All these are some examples of the applications of the privateinterest views in the analysis of financial and banking regulation. ${ }^{6}$

There are studies specifically related to deposit insurance based on the private-interest theory. In a historical study, Calomiris and White (1994) argue that smaller and poorly diversified unit banks in the US benefitted from the FDIC and that their pleas for deposit insurance could not have overcome the larger banks' political opposition had it not been the erosion of the public's confidence in the banking system due to the Great Depression. Based on a model of monopolistic competition between small and large banks as well as empirical and historical evidence, Economides et al. $(1996,1999)$ show that the introduction of bank branching restrictions and federal deposit insurance in the US was motivated by political considerations for the benefit of the small unit banks that were unable to compete effectively with large, multi-unit banks. Similarly, Kane (1997) points out further that deposit insurance protects small banks and depositors at the expense of taxpayers. Kroszner and Strahan (2001), and Laeven (2004) point out that deposit insurance is favored by riskier banks. Deposit insurance will be favored by large banks as well so long as it is under-priced (e.g., Kane and Wilson 1998, Laeven 2002, among others). Laeven (2004) provides evidence in support of the private-interest view as deposit insurance coverage is significantly higher in countries where poorly capitalized banks dominate the industry. Carr et al. $(1994,1995)$ demonstrate that CDIC was set up in 1967 based on a political motive - to enable the weaker trust and mortgage loan companies (TMLs) to compete with the large and stable chartered banks - rather than banking instability. After reviewing the two main theoretical approaches -- economic approach (grounded on economic gains and motivated by public interest) and the political approach (grounded on power of political interest groups and motivated by private interest) - and the empirical evidence, Calomiris and Jaremski (2016) conclude that the latter approach is more consistent with the facts.

\footnotetext{
${ }^{6}$ For details, see Barth et al. (2006), who offer an excellent brief survey of the different approaches to banking regulation.
} 


\subsection{Theories of Bureaucracy and Lessons from the Literature}

Besides the private-interest theory, our theory is related to another strand of literature, namely the bureaucratic behavior of government officials, including regulators and central bankers. Our notion that bureaucrats are basically in the business to make a living so as to maximize their own personal interests can be traced back to as early as Tullock and McKenzie (1985), Acheson and Chant $(1972,1973)$ and Niskanen (1971), to name just a few. In Niskanen's celebrated model, for example, government bureaucrats gain from the growth of bureaucracy because an official's power, opportunities for promotion and other perquisites are positively correlated with the budget the bureaucrat administers, whereas Acheson and Chant (1972, 1973) are among the first to apply the bureaucratic theory to study central bank's behavior though not a deposit insurance provider - in the choice of monetary instruments and goals.

Several lessons can perhaps be learned from the above brief literature survey. First, the capture theory does not explain satisfactorily why regulators have to be captured; in fact, they do not necessarily have to be captured by any stakeholders of the regulation. Second, regulation is costly. So even if the regulator cares about the public interest or his own self-interest, he has to compare the costs and benefits of regulation. Third, there is no reason to believe that the regulator would care about the transfer of wealth from one interest group to another unless the regulator himself also gains from this wealth redistribution process. Last but not least, the moral hazard problem associated with deposit insurance can lead to such high social costs of bank failures in the long run that they outweigh the social benefits. In sum, a satisfactory explanation for EDIS adoption may have to go beyond the public-interest and capture theories.

\section{A Bureaucratic-Entrepreneurial Theory}

To explain EDIS adoption, we formulate a simple theory in which the regulator (deposit insurance provider) plays a dual role as both a bureaucrat and an entrepreneur to maximize his own self-interest. For simplicity, the regulator's utility is assumed to be a function of his effort $(\xi)$ put into the regulatory process and the gross profits $(\pi)$ generated from administering the deposit insurance fund. Apparently the higher his effort, the lower is his utility. Contrarily, the higher the gross profits, the higher is his utility because he can enjoy a higher salary, fringe benefits, office expense, etc. (e.g., Niskanen 1971). The utility function has the standard assumptions like continuity, twice differentiability: $U=\mathrm{U}(\xi, \pi)$. As an illustrative example, Figure 1 depicts the regulator's three indifference curves $U_{0}, U_{l}$ and $U_{2}$, where the levels of utility are $U_{2}>U_{0}>U_{1}$. 
Figure 1: Indifference Curve Analysis of the Regulator's Choice

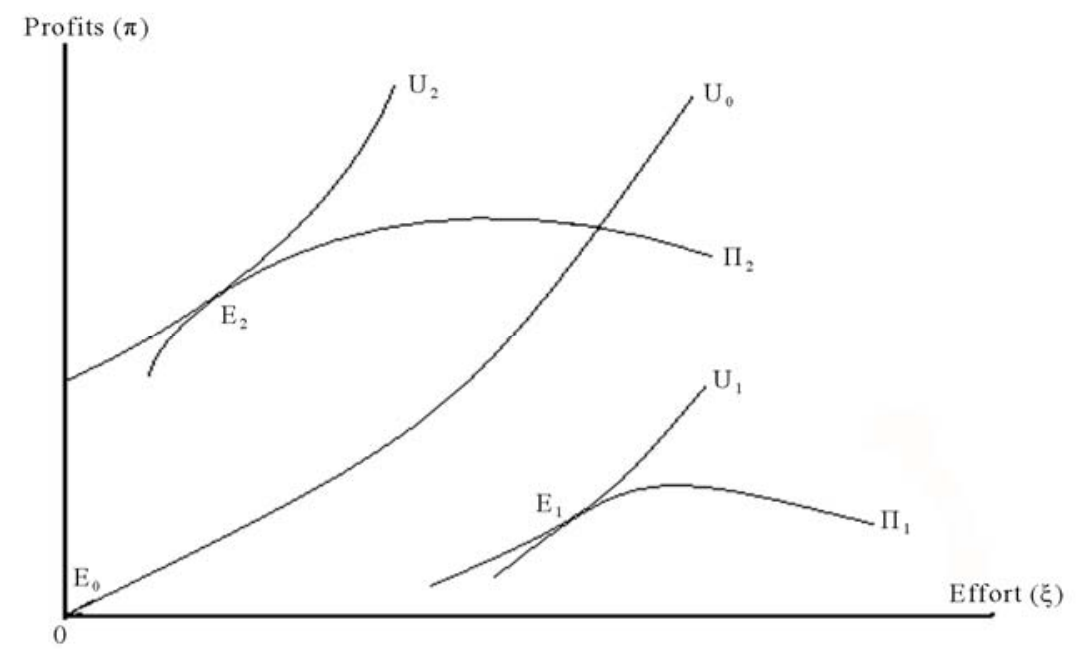

For the second argument $\pi$ in the utility function, the regulator acts as an entrepreneur who has a profit motive to derive his salary, fringe benefits, etc., from his job as a manager for administering the deposit insurance fund. Without the fund, his salary and fringe benefits rely on the financial resources allocated by the government to banking regulation. In contrast, the regulator enjoys a higher degree of autonomy in deciding his own remunerations or office expenses with a fund. Similar to Kane (1989), the deposit insurance fund's gross profits $(\pi)$ is specified as ${ }^{7}$

$$
\pi=\rho D+r I-C_{m}-C_{L}
$$

where $\rho$ is the insurance premium, $D$ is the deposits insured, $r$ is the average rate of return on investment assets held by the fund, $I$ is the amount of investment by the fund, ${ }^{8} C_{m}$ is the cost of monitoring insured banks, and $C_{L}$ is the losses incurred in resolving bank insolvencies. For analytical tractability, $D$ is assumed to be exogenously given.

\footnotetext{
${ }^{7}$ Kane's model can be conceived as a multi-period model in which the market value of the insurance enterprise - the Federal Savings and Loan Insurance Corporation - is the present value of a perpetuity of future cash flows discounted by the insurer's cost of capital. Without loss of generality, we focus here on the cash flows or gross profit only.

${ }^{8}$ Our results will remain intact even if $r$ and $I$ in Equation (1) are omitted by assuming that the EDIS has no investment assets when it is initially launched.
} 


\section{KAM HON CHU Theory of Deposit Insurance Adoption}

Monitoring cost is directly under the regulator's control and is an increasing function of his effort, and it follows the standard assumptions for a typical cost functions, i.e., $C_{m}=C_{m}(\xi)$, and $\partial C_{m} / \partial \xi>0$ and $\partial^{2} C_{m} / \partial \xi^{2}>0$. The cost function $C_{L}$ is not directly under the regulator's control but is related to the monitoring effort or cost. Furthermore, the cost is related to the deposits insured. It is assumed that $C_{L}=k D$, where $k=k\left(C_{m}\right), k^{\prime}<0$ and $k^{\prime \prime}>0$, i.e., the regulator's higher level of monitoring can reduce the losses due to bank failures but there are diminishing returns to his monitoring efforts.

It is straightforward to show that the signs of $\partial \pi / \partial \xi$ and $\partial^{2} \pi / \partial \xi^{2}$ depend on the relative magnitudes of changes of $C_{m}$ and $k$ with respect to a change in $\xi^{9}$ But like typical cost functions, it is reasonable to assume that $C_{m}$ is low but $C_{L}$ is high for $\xi=0$ or for low levels of $\xi$ because more banks may fail as a result of lax monitoring and moral hazard. Consequently, $\pi \leq 0$. With increasing monitoring effort, the (expected) losses from bank failures can be reduced such that $\partial \pi / \partial \xi>0$. But increasing monitoring cost on the one hand and diminishing returns to efforts on the other implies $\partial \pi / \partial \xi=0$ at some $\xi$ and $\partial \pi / \partial \xi<0$ beyond this level. ${ }^{10}$ In other words, the profit function is concave downward in the $\pi-\xi$ plane but its position depends on the values of the given parameters and exogenous variables, i.e., $\rho, D, I$ and $r$.

Therefore, a regulator can potentially make profits from an EDIS; but whether he will actually do so still depends on some other factors. In a non-democratic society or centrally planned economy, for example, the bureaucrat does not necessarily adopt an EDIS if the government has already had a high ownership of banks, because instituting and administering a new EDIS means duplication of resources or efforts without any extra benefits to him. This should also be the case in democratic societies.

In a democratic society, a further determinant is the acceptability or popularity of an EDIS among the various stakeholders involved. One conventional theory of regulation postulates that politicians in a democratic society would introduce an EDIS to "buy" votes from depositors. But as already mentioned, casual empiricism does not support this hypothesis because none of the EDIS was introduced with a referendum or had been an issue in an election campaign.

Instead, it is more likely that banks rather than depositors are the major players in the political game. Without loss of generality, we assume that the banking industry consists of two groups - "good" and "bad" banks. Or one can think of two groups of depository institutions, like chartered banks and TMLs in the case of Canada. Because of cross-subsidization under an EDIS with a non-risk rated premium, bad banks gain while good banks lose. Based on the ideas of Peltzman (1976) and Becker (1983), we postulate that in a democratic society the political

\footnotetext{
${ }^{9}$ From Equation (1), it is straightforward to show that $\partial \pi / \partial \xi=-C^{\prime}{ }_{m}-k{ }^{\prime} C^{\prime}{ }_{m} D$ and $\partial^{2} \pi / \partial \xi^{2}=-C^{\prime}{ }_{m}-$ $\mathrm{k}^{\prime \prime} \mathrm{C}^{\prime}{ }_{\mathrm{m}}^{2} \mathrm{D}-\mathrm{k} \mathrm{C}^{\prime}{ }_{\mathrm{m}} \mathrm{D}$. Both expressions can be positive or negative.

${ }^{10}$ At the margin, $\partial \pi / \partial \xi=0$ when the monitoring cost is equal to the cost of resolving insolvency.
} 
support function (P) or influence function is a function of the two interest groups' spending on lobbying: ${ }^{11}$

$$
P=P\left(N_{2} L_{2}-N_{1} L_{1}\right)
$$

where $N_{1}$ and $N_{2}$ are the numbers of good and bad banks, and $L_{1}$ and $L_{2}$ are respectively each group's average expenditure on lobbying against and for an EDIS. If bad banks spend more on lobbying than good banks, the regulator will introduce an EDIS to increase bad banks' welfare; otherwise, the status quo remains. Assuming perfect information and no random shocks, the two interest groups compete for control of government policy by their expenditure on lobbying. Consider the initial condition before the introduction of EDIS. To simplify the algebra, assume each group consists of $N_{i}$ identical banks so that a representative bank's profit $\pi_{i}$ in group $i$ can be expressed as proportional to its deposits or market share:

$$
\pi_{i}=\phi S_{i}
$$

where $\phi$ is the profit per unit of deposit and $S_{i}$ is the bank's deposits, where $S_{1}>S_{2}$, i.e. good banks have larger market shares.

Then each bad bank lobbies for EDIS by spending $L_{2}$ whereas each good bank responds by lobbying against it by spending $L_{1}{ }^{12}$ If $L_{1} N_{1} \geq L_{2} N_{2}$, no EDIS will be introduced and a bank's profit will be ${ }^{13}$

$$
\pi_{i}=\phi S_{i}-L_{i}
$$

Conversely if $L_{1} N_{1}<L_{2} N_{2}$, EDIS will be introduced and a good bank's profit will become

$$
\pi_{1}=\varphi\left(S_{1}-T\right)
$$

whereas a bad bank's profit will be

\footnotetext{
${ }^{11}$ The notion of competition among pressure groups and lobbying can be traced back to at least Olson (1965) and subsequent works include Grossman and Helpman (2001), among others.

${ }^{12}$ For simplicity and analytical tractability, our model is deterministic. In the case of uncertainty or imperfect information about the extent of lobbying, $L_{1}$ and $L_{2}$ can be replaced respectively by their expected values based on the banks' subjective beliefs.

${ }^{13}$ We assume zero cost in organizing the banks into a group in the lobbying process. This is not crucial in affecting our results so long as both good and bad banks face the same non-zero per unit organizing cost.
} 


\section{KAM HON CHU Theory of Deposit Insurance Adoption}

$$
\pi_{2}=\varphi\left(S_{2}+T\right)
$$

where $\varphi$ is the new profit per unit of deposit (i.e., net of deposit insurance premium) and $T$ is the transfer of market share from a good bank to a bad bank. Here the deposit insurance premium is assumed to be non-risk rated or actuarially unfair such that there is a transfer or cross-subsidization from good banks to bad banks in terms of redistribution of deposits or market shares. ${ }^{14}$

In this model of interest group competition, a representative bad bank makes a first move by choosing $L_{2}$, where $0 \leq L_{2} \leq L_{2}$, to lobby for EDIS. The maximum spending on lobbying, $L$ 2 , is determined by the difference between its profits determined by Equations (6) and (4). In response, a good bank chooses $0 \leq L_{1} \leq L_{1}$, to lobby against EDIS, where the maximum spending on lobbying, $L_{1}$, is determined by the difference between its profits determined by Equations (4) and (5). It is obvious that the good bank's optimal response is to set $L^{*}{ }_{l}=L_{2} N_{2} / N_{I}$ and $L^{*}{ }_{1} \leq L_{1}$, for whatever $L_{2}$ is chosen by the bad bank provided that $L^{*}{ }_{1}$ is affordable and profitable. However, the number of bad banks, $N_{2}$, can be so large that it is no longer profitable for good banks to set $L_{1}=L_{2} N_{2} / N_{1}$ and, if so, the optimal $L^{*}{ }_{1}=0$. By substituting $L_{1}$ and $L_{2}$ into the inequality $L_{1} N_{1}<L_{2} N_{2}$, EDIS may be introduced if the following condition is satisfied:

$$
\varphi\left(N_{2}-N_{1}\right) T>(\phi-\varphi)\left(N_{1} S_{1}+N_{2} S_{2}\right)
$$

which depends on the structural characteristics of the banking industry, like the numbers of good and bad banks as well as their market shares. Apparently this inequality is more likely to be satisfied when, all other things equal, the number of bad banks or the value of transfer, or both, is larger.

Equation (7) is only a necessary condition as the EDIS adoption still depends on the regulator's final decision. Formally the regulator's problem is: choose $\xi$ to maximize $U=U(\xi$, $\pi)$ subject to the following constraints: (i) the profit function (1), (ii) political support for EDIS (i.e., Equation (7) is satisfied), and (iii) the solution to the optimization problem $U^{*}=U\left(\xi^{*}, \pi^{*}\right)$ $>U_{0}=U(\xi=0, \pi=0)$, i.e., an improvement in his welfare by introducing EDIS.

Diagrammatically, Figure 1 shows the iso-profit lines labelled as $\Pi_{1}$ and $\Pi_{2}$ for two levels of insured deposits $D_{1}$ and $D_{2}$ respectively, where $D_{2}>D_{1}$, all other things equal. Given the iso-profit lines and the regulator's indifference curves, we can determine diagrammatically whether a utility maximizing regulator will introduce EDIS or not. Suppose the regulator's

\footnotetext{
${ }^{14}$ For the debate on the feasibility of fairly priced deposit insurance, see Chan et al. (1992) and Freixas and Rochet (1998).
} 
initial equilibrium is at the origin before the introduction of EDIS. ${ }^{15}$ His initial utility is represented by the indifference curve $U_{0}$. Whether the introduction of EDIS will raise his utility or not depends on the new equilibrium under EDIS, which is determined by the tangency between an indifference curve and an iso-profit line under EDIS.

To illustrate, consider the iso-profit line $\Pi_{l}$ that represents a given level of deposits $\left(D_{l}\right)$. The utility maximization equilibrium is at $E_{l}$ with a utility level $U_{l}$, which is lower than the initial level $U_{0}$. In this case, it does not pay for the regulator to introduce EDIS even though there is political support for it. Because of the insufficient gross profits generated from administering a deposit insurance fund, the regulator would find himself better off by enjoying leisure or pursuing other activities that may advance his political career, say, socializing with politicians, instead of administering the fund.

Obviously, the volume of insured deposits is one of the key factors that determine whether the deposit insurance fund can generate a sufficiently high level of expected profits. Suppose the volume of insured deposits is sufficiently high, say, $D_{2}$ as in the case of $\Pi_{2}$, and all other things equal. Then in this case the regulator would be better off by introducing EDIS because the new equilibrium $E_{2}$ is on an indifference curve $U_{2}$ with a higher level of utility than $U_{0}$.

In sum, the regulator in our model plays a role in redistributing deposits (and hence wealth) from good banks to bad banks through cross-subsidization under a flat-rate or mis-priced EDIS and at the same time he gains from administering the EDIS. For analytical tractability, one potential gain of the regulator from the revolving door - i.e. the regulator's later move into the lobbying industry - is not considered here and is left for future research. ${ }^{16}$

Based on the above exposition and applying Mackie's (1965) INUS-conditions approach, we can infer or postulate the following empirically testable hypotheses, each of which is related to a factor or an INUS-condition: ${ }^{17}$

\footnotetext{
${ }^{15}$ For simplicity and convenience, the regulator's initial effort in regulating banks in the absence of EDIS is normalized to equal to zero. The horizontal axis in Figure 1 thus measures the regulator's "extra" effort under an EDIS.

${ }^{16}$ For studies related to the revolving door, see, for example, the theoretical model by Che (1995) and the empirical study by Vidal et al.(2012), although these two studies are generic and do not address specifically the case of deposit insurance.

${ }^{17}$ According to Mackie's INUS-conditions for causality, each factor is an Insufficient but Non-redundant part of an Unnecessary but Sufficient condition for the effect or an event. A classic example is: a short circuit causes a house fire. The short circus is an inus-condition because it is insufficient to cause the fire on its own without the presence of other conditions like oxygen, inflammable material, etc., and it is non-redundant because the other conditions cannot cause a fire without it. Taken together, they form a sufficient condition to cause a fire. But it is not a necessary condition because some other conditions can also cause a fire. We will apply this approach to illustrate our case of deposit insurance adoption below.
} 


\section{KAM HON CHU Theory of Deposit Insurance Adoption}

(i). For the regulator to play a dual role as a bureaucrat and an entrepreneur at the same time, our theory predicts that when an EDIS is adopted the scheme is expected to be officially administered or managed by the public sector, or at least jointly between the public and the private sector.

(ii). By the same token, the source of funding of the EDIS is expected to mainly come from the private sector (say, banks) rather than from the government.

(iii). The larger the volume of deposits, the more likely is EDIS adoption. This is because of larger expected profits earned by regulators as well as larger transfers received by bad banks. Moreover, the larger the volume of deposits, the larger and more rapid for the deposit insurance fund to build up, thus generating greater profits and hence higher utilities for the regulator. ${ }^{18}$

(iv). EDIS adoption is more likely when there are at least two groups of banks with distinguishable characteristics such that one group will relatively gain from EDIS. As long as deposit insurance is mispriced, all incumbents, both big and small banks, gain. But smaller and riskier banks are likely to benefit more from EDIS. If the banking industry is dominated by a few large banks, they are more likely to resist EDIS adoption because they are more likely to lose from the wealth transfers under EDIS arising from increased competition from smaller banks or new entrants; big banks also have the privilege of enjoying the subsidies from implicit deposit insurance under the regulator's too-big-to-fail policy. Therefore, a higher concentration ratio in the banking industry, which suggests stronger dominance of larger banks, tends to lower the likelihood of EDIS adoption.

This prediction based on concentration ratio can be formally inferred from the interest-group competition in our model above as Equation (7) can also be expressed as

$$
\frac{\varphi\left(N_{2}-N_{1}\right) T}{(\phi-\varphi)}-N_{2} S_{2}>N_{1} S_{1}
$$

The right-hand side of this inequality is good banks' market share. If the concentration ratio is high, Equation (8) is less likely to be satisfied and hence a lower political support for EDIS.

\footnotetext{
${ }^{18}$ This finding can be formally derived from our model. From the regulator's indirect utility function $\mathrm{V}$ and the Envelope Theorem, we have $d V / d D=\partial U / \partial \pi(\rho-k)$. On the surface, $d V / d D$ can be positive or negative depending on $(\rho-k)$. But similar to a firm's shutdown point at which it produces no output if price falls below minimum average variable cost, the regulator can choose not to launch EDIS. From Equation (1), this "shutdown point" is found by setting $\pi \geq 0, I=0$ and $\xi=0$ (thus $C_{m}=0$ ), which means $(\rho-k) D \geq 0$ for any arbitrary $D \geq 0$, or simply $(\rho-k) \geq 0$. The economic interpretation is that the deposit insurance premium has to be set, ex ante, at a rate high enough to cover the (expected) deposit loss per dollar deposit, or else it makes no economic sense to introduce EDIS. Therefore, we have $d V / d D \geq 0$.
} 
(v). When an EDIS is initially introduced, the insurance premium is expected to be non-risk rated or mispriced rather than risk-rated in order to render cross subsidization and transfer of wealth from good banks to bad banks.

(vi). For the transfer to be effective, membership of EDIS is expected to be compulsory, or else good banks would opt out.

(vii). If all or most banks are government-owned, then these banks already have implicit government guarantee of their deposits and hence it is less likely or necessary for EDIS adoption because there is no need for the regulator to sell his products (i.e. transfers through regulation and deposit insurance) to banks. Put differently, EDIS are more likely to be adopted by banking industries in which most banks are privately owned.

(viii). Given (iv) above and the notion of interest-group competition, EDIS adoption is more likely in economies with higher levels of democracy or economic freedom such that one group of banks can influence the political process and gain from EDIS.

In Mackie's sense, to say that the regulator's bureaucratic-entrepreneurial behavior causes EDIS adoption is to say that the former is an inus-condition for the latter. The bureaucraticentrepreneurial behavior is an insufficient part because it cannot cause EDIS adoption on its own. The above conditions should also be present. It is, however, a non-redundant part because, without it, the other conditions are not sufficient for the adoption. It is just a part, and not the whole, of a theoretically sufficient condition (i.e., the behavior plus combinations of (i)(viii) above). However, this whole sufficient condition is not necessary, because some other conditions can also lead to EDIS adoption (e.g. the Great Depression and the setup of FDIC). ${ }^{19}$

\section{Empirical Evidence}

To test our theory, we examine the statistics on EDIS before we proceed with formal econometric analysis. Unless otherwise specified, the main databases employed are those compiled by Demirgüç-Kunt et al. (2014, 2015), Demirgüç-Kunt et al. (2005) on deposit insurance and those by Barth et al. $(2006,2013)$ on banking regulation.

As a data exploration process, we first examine and compare the economies which have already set up EDIS by 2013 with those without EDIS regarding certain socio-economic

\footnotetext{
${ }^{19}$ Such a systemic banking panic is sufficient for justifying EDIS adoption as a remedial measure because deposit insurance can have a short-run therapeutic effect in aborting the crisis (Friedman and Schwartz 1963, pp. 163-8). This reason for EDIS adoption due to occurrence of banking crisis is, however, not incompatible with our theory. Our model is deterministic and banks are not subject to random shocks like banking crises. Nevertheless, in the absence of EDIS a banking crisis tends to adversely affect bad banks more than good banks for there could be a redistribution of deposits from bad to good banks due to depositors' flight to quality. Accordingly, bad banks would have stronger incentives to lobby EDIS adoption in order to retain their market shares. See also what happened in the case study of Canada below.
} 
variables relevant to our theory. They include the deposits-GDP ratio, the five-firm concentration ratio of the banking industry, government ownership of banks, experience of banking crisis, and the extent of economic and political freedom. ${ }^{20}$ All data are from the above databases except the deposits-GDP ratio and the level of political participation, which are respectively from the World Bank's Global Financial Development database and the Fraser Institute's Annual Report of Economic Freedom. Data for 2011 are compared and the summary statistics are tabulated as Table 1.

The deposits-GDP ratio is used as a measure of size of the banking system relative to size of the economy. As our theory predicts, economies with higher deposits-to-GDP ratios are more likely to set up EDIS. ${ }^{21}$ The five-firm concentration ratio of the banking industry is used as a proxy to reflect the extent of heterogeneity in bank size, i.e. to capture the notion of good banks versus bad banks in our model and the empirical prediction (iv) mentioned above. The lower the concentration ratio, the banking industry is less likely to be dominated by the five largest banks; and hence it is more likely for smaller banks to lobby the government to set up an EDIS for them to gain from cross subsidization. Government ownership of banks refers to the percentage of banking system's assets in banks that are $50 \%$ or more owned by government.

Table 1: Descriptive Statistics for the Explanatory Variables

\begin{tabular}{|l|c|c|c|c|c|}
\hline & Mean & $\begin{array}{c}\text { Standard } \\
\text { Deviation }\end{array}$ & Min & Max & $\begin{array}{c}\text { No. of } \\
\text { Obs. }\end{array}$ \\
\hline \hline Deposits/GDP (\%) & 59.62 & 50.15 & 9.59 & 339.68 & 106 \\
\hline Concentration Ratio (\%) & 78.47 & 19.59 & 10.61 & 100 & 91 \\
\hline $\begin{array}{l}\text { Government Ownership of } \\
\text { Banks (\%) }\end{array}$ & 15.18 & 18.03 & 0 & 73.7 & 119 \\
\hline Economic Freedom & 6.98 & 0.76 & 3.96 & 8.91 & 101 \\
\hline
\end{tabular}

Note: The numbers of observations are not the same across the board because of data availability.

\footnotetext{
${ }^{20}$ We have also experimented with: (i) the Democracy Index and the index of political participation published by the Economist Intelligent Unit (2011); (ii) the political rights index and civil liberties index by the Freedom House (2016) and (iii) a dummy variable representing an electoral regime. The results, however, remain qualitatively similar. For brevity, we report only the findings based on the Economic Freedom Index by the Fraser Institute (2012).

${ }^{21}$ The public-interest view also has this prediction but with reverse causality - deposit insurance makes bank deposits more attractive and hence a higher deposits to GDP ratio.
} 
According to our theory, the higher the level of government bank ownership, it is less likely for politicians or bureaucrats to have the needs or incentives to set up EDIS to maximize their own interests. $^{22} 23$ To partly reflect competition between interest groups, the Economic Freedom Index is used as a proxy variable and reported here. In general, the index value is high for democracies and low for authoritarian regimes; and interest groups are more likely to participate in the political process so as to lobby the government to set up EDIS under a higher level of economic freedom or political participation. Finally, we include the experience of banking crisis as a control variable. It is a dummy variable with a value of one if an economy had at least a systemic banking crisis in previous years and a value of zero if it has never had any systemic crisis. Intuitively, economies which experienced banking crises are more likely to set up EDIS to avert the recurrence of banking crises. Admittedly, the cross-sectional specification is subject to limitations and criticisms, particularly in capturing the actual timing of EDIS adoption. For example, EDIS adoption now may have little to do with a crisis occurred a long time ago. Or take the US as another example - the recent US data would have little to do with the introduction of FDIC in $1934 .^{24}$ As such, the regression results below should perhaps be appropriately interpreted as the likelihood to find a country with EDIS given the set of attributes observed at any given moment, say, the year 2013 in our case, rather than as the country's choice to adopt EDIS in response to those attributes over time. We shall provide further empirical findings below to address this timing or causation problem.

We first compare the economies with and without EDIS with respect to the above explanatory variables. As can be seen from Table 2, economies with EDIS have on the average a higher deposits-GDP ratio and also a higher level of economic freedom but a lower five-firm

\footnotetext{
${ }^{22}$ An alternative explanation is: deposits at government-owned banks can be perceived as a form of government debt and if the government can print money to pay off this debt, then it is less likely or unnecessary for the government to set up an EDIS when the government has a high ownership of banks. This hypothesis, however, seems to be less widely applicable than ours because monetization of such government debt may be infeasible in certain countries, e.g. the Eurozone.

${ }^{23}$ In theory, the relationship between government ownership of banks and EDIS adoption may not be so simple. If the government-owned banks are so large that they have de facto implicit deposit insurance and make smaller banks at a competitive disadvantage, smaller banks may hence favor EDIS in order to level the playing field. In other words, there is potentially an interaction effect between concentration ratio and government ownership of banks. However, we find this interaction effect to be statistically insignificant.

${ }^{24}$ One possible approach to taking care of this timing problem is to consider countries that have no EDIS in period $t=0$ and then model and estimate the hazard function of adopting EDIS in subsequent periods. I am indebted to Professor Peltzman for this suggestion. Unfortunately, the currently available data for the explanatory variables do not make this approach operationally feasible. As will be seen below, we provide further empirical results to address this timing or causation problem in EDIS adoption.
} 
KAM HON CHU Theory of Deposit Insurance Adoption

Table 2: Comparison of Economies with and Without EDIS

\begin{tabular}{|c|c|c|c|c|}
\hline & Without EDIS & With EDIS & Total & Equality Test \\
\hline Number of Economies & 78 & 112 & 190 & n.a. \\
\hline Deposits/GDP & $\begin{array}{c}44.0 \% \\
(31)\end{array}$ & $\begin{array}{c}66.0 \% \\
(75)\end{array}$ & $\begin{array}{l}59.6 \% \\
(106)\end{array}$ & $-2.87 * * *$ \\
\hline Concentration Ratio & $\begin{array}{c}87.4 \% \\
(18)\end{array}$ & $\begin{array}{c}76.3 \% \\
(73)\end{array}$ & $\begin{array}{c}78.5 \% \\
(91)\end{array}$ & $2.93^{* * *}$ \\
\hline $\begin{array}{l}\text { Government Ownership } \\
\text { of Banks }\end{array}$ & $\begin{array}{c}17.2 \% \\
(34)\end{array}$ & $\begin{array}{c}14.6 \% \\
(83)\end{array}$ & $\begin{array}{c}15.3 \% \\
(117)\end{array}$ & 0.65 \\
\hline Economic Freedom & $\begin{array}{c}6.6 \\
(26)\end{array}$ & $\begin{array}{c}7.1 \\
(75)\end{array}$ & $\begin{array}{c}6.98 \\
(100)\end{array}$ & $-2.74 * * *$ \\
\hline Banking Crisis & $\begin{array}{c}11 \\
(33)\end{array}$ & $\begin{array}{c}49 \\
(79)\end{array}$ & $\begin{array}{c}60 \\
(112)\end{array}$ & $-2.87 * * *$ \\
\hline
\end{tabular}

Notes:

1. For deposits/GDP, concentration ratio, government ownership of banks and economic freedom, the reported figures are their average values.

2. Figures in parentheses are the numbers of observations included in the calculations.

3. The total number of observations in each category does not equal to 190 because data for some economies are unavailable.

4. For the test of equality of means reported in the last column, the figures are the SatterthwaiteWelch t-statistics; although the results and inference are qualitatively intact using the traditional tstatistics. These are two-tail tests and the conclusions remain unchanged and reinforced if one-tail tests are used instead.

5. *** denotes statistical significance at the one-percent level.

6. A full list of economies with or without EDIS can be found in Table 1 of Demirgüç-Kunt et al. (2014).

concentration ratio and a lower level of government ownership of banks. As expected, a larger proportion of economies with EDIS has experienced systemic banking crises - almost 4/5 when compared with only $1 / 3$ in those economies without EDIS. More formally, the test results of equality of means based on the Satterthwaite-Welch t-statistics clearly indicate that the means of all these variables, except government bank ownership, are statistically different between these two groups of economies. ${ }^{25}$ In sum, these facts or statistical findings are consistent with the predictions of our theory.

Next we check the design features of EDIS that are relevant to our theory. Apparently our theory predicts that EDIS should be publicly administered or at least jointly administered by

25 The Satterthwaite-Welch t-statistics are used because the variances of these variables are not homogeneous between these two groups. Nonetheless, the statistical inference and conclusion remain intact even if we assume equal variances and apply the traditional t-statistics. 
the public and private sectors, or else there would be no role for the politicians or bureaucrats to play. On the other hand, sources of funding for EDIS are expected to come from the private sector rather than the government because, according to our theory, the politicians or bureaucrats derive utilities from higher profits. Our theory also suggests compulsory membership in EDIS and also non-risk rated deposit insurance premium in order to result in cross subsidization from good banks to bad banks. ${ }^{26}$

These features of 111 EDIS as of 2013 are tabulated as Table 3. As can be seen, membership is compulsory across all EDIS. Most schemes have non-risk rated deposit insurance premiums, although there are more schemes with risk-rated premiums than before. The majority of these schemes are publicly administered, followed by joint administration. By contrast, sources of funds largely come from the private sector, and only two schemes are publicly funded. ${ }^{27}$ Once again, all these features are consistent with the predictions of our theory.

As a formal empirical analysis, we proceed with an estimation of the determinants of EDIS adoption based on a binary-choice dependent variable model. Similar to but not exactly the same as Demirgüç-Kunt et al. (2008), our analysis examines a cross-sectional data for countries by estimating respectively a logit model and a probit model (e.g. Greene 2008$)^{28}$, in which the dependent variable is the existence of an EDIS as of 2013. In general the model is specified as:

$$
D I_{i}=f\left(X_{i}, \widetilde{\varepsilon}\right)
$$

where $D I_{i}=1$ for economy $i$ if it has already set up an EDIS by 2013 and $D I_{i}=0$ otherwise; the vector $X_{i}$ is a vector of the explanatory and control variables as of 2011, and $\varepsilon$ is a random disturbance term. According to our theory, the explanatory or proxy variables include the deposits-GDP ratio, the five-firm concentration ratio, government ownership of banks, the extent of economic freedom (or the level of political participation or democracy, whichever

\footnotetext{
${ }^{26}$ Our predictions about these design features are based on our theory and the current EDIS arrangements in the world. Historically, there had been private or state-sponsored, not national, EDIS. There were also other institutional arrangements, such as clearinghouses, to deal with bank runs. For details, see Kroszner and Melick (2008), Calomiris and White (1994), Gorton and Mullineaux (1987), to name just a few.

${ }^{27}$ Details of these characteristics of EDIS by individual country and by income group can be found in Demirgüç-Kunt et al. (2014, 2015).

${ }^{28}$ The random disturbance term in a logit model follows a logistic distribution. To allow for other possible distributions, we have also estimated a probit model (normal distribution) and a gompit model (skewed, extreme value distribution). For brevity, only the logit and probit regression results are reported because their results are qualitatively similar. We shall compare our approach and results with those of Demirgüç-Kunt et al. (2008) in the subsequent discussion.
} 
KAM HON CHU Theory of Deposit Insurance Adoption

Table 3: Design Features of EDIS

\begin{tabular}{|c|c|c|c|}
\hline \multirow{2}{*}{ Administration } & Public & Joint & Private \\
\hline & $73 \quad(65.8)$ & $25 \quad(22.5)$ & $13 \quad(11.7)$ \\
\hline \multirow{2}{*}{ Source of Funding } & Private & Joint & Public \\
\hline & $86 \quad(77.5)$ & $23 \quad(20.7)$ & $\begin{array}{ll}2 & (1.8) \\
\end{array}$ \\
\hline \multirow{2}{*}{ Membership } & Compulsory & Voluntary & \\
\hline & $111(100)$ & $\begin{array}{ll}0 & (0) \\
\end{array}$ & \\
\hline \multirow{2}{*}{ Insurance Premium } & Non-Risk Rated & Risk Rated & \\
\hline & $77 \quad(69.4)$ & $34 \quad(30.6)$ & \\
\hline
\end{tabular}

Note: The figures in parentheses represent the percentages of the total number (111) of EDIS.

appropriate), compulsory membership in EDIS, non-risk rated deposit insurance premium, the nature of the administration of EDIS, and source of funding of EDIS. Data on the first four variables are obtained or computed from the above databases. The last four explanatory variables are dummy variables. The dummy variable Membership in EDIS equals to one if it is compulsory and zero otherwise. The Deposit Insurance Premium dummy variable equals to one if it is non-risk rated and zero if it is risk rated. The indicator variable Administration equals one if an EDIS is publicly administered, and zero otherwise. Similarly, the dummy variable Funding equals one if the EDIS funding comes from only private sources, and zero otherwise. For the control variables, we experiment with some potential determinants of EDIS adoption not explained by our theory. They include experience of systemic banking crisis, external political pressure from the European Union, World Bank or the International Monetary Fund. In the case of European Union, we include a dummy variable EU Accession -- which equals one if a European country became an EU member or in an EU accession process subsequent to the 1995 Fourth Enlargement, and zero otherwise, to reflect the EU's Directive of 1994 which encourages member countries to adopt EDIS. In the case of World Bank and the IMF, a dummy variable called IMF Influence is included -- which equals one if an economy established an EDIS after 1999 and zero otherwise -- to reflect the fact that in 1999 the IMF endorsed deposit insurance as good banking practice (Garcia 1999). This dummy variable aims to capture the influence from the IMF as well as emulation by economies which believed EDIS to be a universal best practice. ${ }^{29}$ Due to limited data availability and our relative small sample size, we try to keep the specification parsimonious and exclude other control variables like

\footnotetext{
${ }^{29}$ We have also experimented with a dummy variable called World Bank Loans -- which is equal to one if a country had an adjustment lending program with World Bank for reforms to establish EDIS, and zero otherwise. Similar to IMF Influence, it is also a perfect predictor in the econometric estimation. However, the IMF Influence is preferred because it covers more economies and also captures not only World Bank loans or IMF restructure programs but also emulation.
} 
systemic risk of the banking system or other macroeconomic variables as in Demirgüç-Kunt et al. (2008).

The actual estimation procedures ran into a separation problem with the following explanatory variables - Membership, Administration, Funding, Deposit Insurance Premium, EU Accession and IMF Influence - irrespective of whether a logit or probit model is employed. Theoretically, this separation problem occurs when a regressor contains a separating value for which all of the observations with values above this threshold value are associated with a single binary response, whereas all values below are associated with the alternative response. Consider membership as an example. If the Membership dummy variable takes a value of zero, the dependent variable also takes a value of zero, whereas if the former equals to one, then the latter also equals to one. Intuitively, this means whenever an EDIS is adopted, its membership is compulsory. As a result, the maximum likelihood estimation method breaks down. Put differently, the regressor is a "perfect predictor" of the dependent variable. One possible solution to this problem is to obtain a larger sample. Another highly popular "solution" is simply to remove these offending regressors from the specification.

We choose the second "solution" partly because of data unavailability and partly because even a larger sample may not necessarily overcome this separation problem if these regressors are really perfect predictor of EDIS adoption in the sense that they are either predetermined or simultaneously determined when an EDIS is decided to be adopted. Take EU Accession as an example. As a policy to integrate national financial markets in the European Union, the EU Directive on Deposit Insurance that came into effect in 1994 dictates that its member countries and candidate countries have to offer deposit insurance coverages. Therefore, EU membership or candidacy will imply the existence of EDIS; consequently in this case a larger sample does not solve the separation problem. This is similarly the case for membership in EDIS, the administration and source of EDIS funding. Even though these regressors are omitted from our specified models, they certainly play a crucial role in determining EDIS adoption. More importantly, the responses of the dependent variable (i.e., EDIS adoption or not) to the regressors - membership in EDIS, the administration and source of funding of EDIS - are all consistent with the predictions of our theory.

After omitting these offending regressors, the logit and probit estimation results are reported in Table 4. We also report the regression results for a linear probability model (LPM) for reference and comparison. The first column of Table 4 reports the logit estimation results. The deposits-GDP ratio has the correct positive sign as predicted but is only marginally significant, whereas the five-firm concentration ratio has the correct negative sign and is statistically significant at the 10-percent level. Government ownership of banks has the correct negative sign but is not statistically significant at the conventional levels. The same holds for the 
KAM HON CHU Theory of Deposit Insurance Adoption

Table 4: Estimation Results of Models of EDIS Adoption

\begin{tabular}{|c|c|c|c|c|}
\hline Model & Logit & Probit & LPM & WLS \\
\hline \multirow[t]{3}{*}{$\overline{\text { Intercept }}$} & 1.8908 & 1.1103 & 0.6561 & 0.6571 \\
\hline & $(0.46)$ & $(0.54)$ & $(1.40) \dagger$ & $(2.57)^{* *}$ \\
\hline & {$[0.44]$} & {$[0.53]$} & {$[1.22]$} & \\
\hline \multirow[t]{3}{*}{ Deposits/GDP } & 2.2471 & 1.1972 & 0.1009 & 0.06 \\
\hline & $(1.50) \dagger$ & $(1.71)^{*}$ & $(1.19)$ & $(1.87)^{*}$ \\
\hline & {$[1.44] \dagger$} & {$[1.65]^{*}$} & {$[2.07]^{* *}$} & \\
\hline \multirow[t]{3}{*}{ Concentration Ratio } & -4.7233 & -2.6671 & -0.5869 & -0.5386 \\
\hline & $(-1.90)^{*}$ & $(-2.26)^{* *}$ & $(-2.91)^{* * *}$ & $(-4.18)^{* * *}$ \\
\hline & {$[-1.82]^{*}$} & {$[-2.19]^{* *}$} & {$[-3.71]^{* * *}$} & \\
\hline \multirow[t]{3}{*}{ Government Ownership of banks } & -1.5978 & -0.8875 & -0.289 & -0.1955 \\
\hline & $(-0.78)$ & $(-0.86)$ & $(-1.20)$ & $(-2.20)^{* *}$ \\
\hline & {$[-0.75]$} & {$[-0.84]$} & {$[-1.09]$} & \\
\hline \multirow[t]{3}{*}{ Economic Freedom } & 0.2284 & 0.1343 & 0.0535 & 0.0597 \\
\hline & $(0.43)$ & $(0.51)$ & $(0.88)$ & $(1.90)^{*}$ \\
\hline & {$[0.42]$} & {$[0.50]$} & {$[0.77]$} & \\
\hline \multirow[t]{3}{*}{ Banking Crisis } & 1.5762 & 0.8446 & 0.1726 & 0.1211 \\
\hline & $(2.42)^{* *}$ & $(2.23)^{* *}$ & $(1.95)^{* *}$ & $(2.66) * * *$ \\
\hline & {$[2.32]^{* *}$} & {$[2.16]^{* *}$} & {$[1.95]^{* *}$} & \\
\hline \multirow[t]{3}{*}{ EU Accession } & & & 0.1607 & 0.1518 \\
\hline & & & $(1.29) \dagger$ & $(4.60) * * *$ \\
\hline & & & {$[2.80]^{* * *}$} & \\
\hline \multirow[t]{3}{*}{ IMF Influence } & & & 0.2815 & 0.2582 \\
\hline & & & $(3.35)^{* * *}$ & $(5.45) * * *$ \\
\hline & & & {$[4.87] * * *$} & \\
\hline McFadden $R^{2}$ or adj. $R^{2}$ & 0.1957 & 0.192 & 0.2194 & 0.2697 \\
\hline S.E.E. & 0.3642 & 0.3661 & 0.3539 & 0.5815 \\
\hline Like. Ratio test or $F$ test & $16.74 * * *$ & $16.42 * * *$ & $4.41 * * *$ & $5.48 * * *$ \\
\hline Hosmer-Lemeshow test & 10.39 & 10.85 & & \\
\hline No. Of Observations & 86 & 86 & 86 & 86 \\
\hline
\end{tabular}

Notes: 1. Figures in parentheses are the z-statistics for the binary-choice dependent variable models and are t-statistics for the linear probability model, whereas figures in brackets are respectively the z-statistics computed from the GLM robust standard errors and the t-statistics computed from the Newey-West heteroscedasticity-consistent standard errors.

2. ***,**, $*$ and + denote respectively statistical significance at the $1 \%, 5 \%, 10 \%$ and $20 \%$ levels.

Economic Freedom Index. ${ }^{30}$ One plausible explanation is that the political process is so complex that it is unlikely to be captured or reflected by a linear numerical index. As expected,

${ }^{30}$ If the political rights or civil liberties index is used as a proxy instead, they also give the correct positive sign. The civil liberties index is statistically insignificant, but the political rights index is marginally significant with a p-value of about 0.13 . However, if democracy, level of political participation or 
the control variable - experience of banking crisis - has a positive sign and is statistically significant at the $5 \%$ level, suggesting that countries with systemic banking crises before are more likely to set up EDIS. Besides the parameter estimates, the McFadden $R^{2}$ for the logit regression is about 0.2 , which is quite acceptable for a cross-sectional regression. This together with the results of the likelihood ratio test and the Hosmer-Lemeshow goodness-of-fit test suggests that this logit model, though parsimonious in terms of the number of explanatory variables, captures some of the major determinants in EDIS adoption.

The probit estimation results are reported in the second column of Table 4. They are qualitatively similar to those of the logit model, although the coefficient estimates are quantitatively different and also that both the deposits-GDP ratio and the concentration ratio have improved in terms of statistical significance.

Although dropping the "perfect predictors" from the regression model is a commonly adopted empirical strategy to overcome the separation problem, this procedure has been criticized because it leads to mis-specification error due to omission of relevant explanatory variables. Against this background, we also report in the penultimate column of Table 4 the regression results of the LPM that includes the EU Accession and IMF Influence as explanatory variables. It serves as a quick check to examine if they are determinants of EDIS adoption. ${ }^{31}$ As can be seen, the parameter estimates are similar to those of the logit and probit regressions as far as the predicted signs and statistical significance are concerned. More importantly, the results reveal that both EU Accession and IMF Influence are significant determinants of EDIS adoption.

The coefficients of the LPM are known to be inefficient because of heteroscedasticity. In addition to the t-statistics computed from the Newey-West heteroscedasticity-consistent standard errors reported for hypothesis testing and inference, Goldberger's weighted least squares (WLS) model is also applied to correct for heteroscedasticity. ${ }^{32}$ As can be seen from the results reported in the last column of Table 4, there are noticeable improvements over the

electoral regime is used as a proxy, they all give the wrong sign though they are statistically insignificant.

31 Arguably, the LPM is not necessarily outperformed by binary-response models because of its advantages such as being easier to use and to interpret than the latter models. For defense of the LPM, see for example Angrist and Pischke (2009).

32 The two-step procedure involves: (i) obtain the predicted values for the endogenous variable, say $\hat{Y}$, based on the LPM and construct the estimated weights as $\hat{Y}(1-\hat{Y})$; and (ii) transform the data by the estimated weights and re-run the LPM. See Goldberger (1964) for details. 


\section{KAM HON CHU Theory of Deposit Insurance Adoption}

original LPM. In particular, government ownership of banks and economic freedom both become statistically significant, thus strengthening the support to our theory. ${ }^{33}$

Though intuitively appealing, these LPM results are suggestive rather than definitive because of the limitations of the LPM, such as the predicted probabilities can lie outside the 0 1 range and the model fails to capture the nonlinear nature of the true population regression function. Therefore, we proceed further with the binary-choice dependent variable models with a different empirical strategy to overcome these limitations and the aforementioned separation problem. For brevity, we again focus on the logit model only. First we repeat the logit regression by excluding the countries which obtained EU accession after 1995 from the sample. Ideally, the regression results should thus be free from mis-specification error (assuming EU accession is the only omitted variable). Put differently, there is a tradeoff: the degree of freedom becomes lower because of a smaller sample, but hopefully we may obtain unbiased estimates due to a correct specification. The regression results are reported in the first column of Table 5. As can be seen, the results are qualitatively the same as the logit regression results reported in Table 4 in terms of the predicted signs but they are somewhat different in terms of the magnitudes of the parameter estimates and statistical significance.

By the same token, we repeat the logit regression by excluding the countries or economies which set up EDIS after 1999 from our sample. Once again, ideally the regression results should be free from misspecification error if IMF Influence is the only omitted variable. The regression results are reported in the second column of Table 5. In this case, the results are considerably different from the previous two sets of results. Particularly, the magnitudes of the parameter estimates have changed noticeably and their statistical significance has also improved. The significantly higher McFadden $R^{2}$ also indicates that this model has a stronger explanatory power in terms of goodness-of-fit than the previous two models.

Similarly, we repeat the logit regression by excluding the countries which obtained EU accession after 1995 and also those economies which set up EDIS after 1999 from the sample. Ideally, in this sample, those economies' decisions to adopt EDIS should not have been subject to the external political pressure arising from the EU or the IMF (assuming other omitted explanatory variables are random in such a way that they are all captured by the random disturbance term). Therefore, the logit regression results are theoretically not subject to misspecification error and hence it is a more appropriate test of our theory. The regression results are reported in the third column of Table 5. They are highly similar to those reported in the

\footnotetext{
${ }^{33}$ Perhaps it should be further pointed out that the Goldberger procedure appears to be an appropriate correction method as the Breusch-Pagan-Godfrey test statistic of 1.29 , not reported in the Table, indicates that the hypothesis of homoscedasticity is not rejected.
} 
Table 5: Further Estimation Results of Logistic Models of EDIS Adoption

\begin{tabular}{|c|c|c|c|c|}
\hline Model & (1) & (2) & (3) & (4) \\
\hline & $\begin{array}{l}\text { Excluding EU } \\
\text { accession } \\
\text { economies }\end{array}$ & $\begin{array}{l}\text { Excluding } \\
\text { EDIS set up } \\
\text { after } 1999\end{array}$ & $\begin{array}{l}\text { Excluding both } \\
\text { EU accession } \\
\text { and EDIS set up } \\
\text { after } 1999\end{array}$ & $\begin{array}{c}\text { Excluding both } \\
\text { EU accession and } \\
\text { EDIS set up after } \\
1999\end{array}$ \\
\hline \multirow[t]{3}{*}{ Intercept } & 2.5496 & 3.9935 & 5.0189 & 3.1096 \\
\hline & $(0.73)$ & $(0.96)$ & $(1.17)$ & $(1.39) \dagger$ \\
\hline & {$[0.71]$} & $\begin{array}{l}0.75] \\
\end{array}$ & {$[0.98]$} & {$[1.20]$} \\
\hline \multirow[t]{3}{*}{ Deposits/GDP } & 1.9508 & 5.0607 & 5.0997 & 4.6553 \\
\hline & $(1.49) \dagger$ & $(2.23)^{* *}$ & $(2.25)^{* *}$ & $(2.36)^{* *}$ \\
\hline & {$[1.45] \dagger$} & {$[1.75]^{*}$} & {$[1.87]^{*}$} & {$[2.03]^{* *}$} \\
\hline \multirow[t]{3}{*}{ Concentration Ratio } & -4.9232 & -7.0531 & -7.3556 & -7.3419 \\
\hline & $(-2.30)^{* *}$ & $(-2.62)^{* * *}$ & $(-2.65)^{* * *}$ & $(-2.67)^{* * *}$ \\
\hline & {$[-2.25]^{* *}$} & {$[-2.05]^{* *}$} & {$[-2.21]^{* *}$} & {$[-2.30]^{* *}$} \\
\hline \multirow[t]{3}{*}{ Government Ownership of Banks } & -1.594 & -1.9748 & -1.4527 & -0.4826 \\
\hline & $(-0.88)$ & $(-0.87)$ & $(-0.65)$ & $(-0.25)$ \\
\hline & {$[-0.86]$} & {$[-0.68]$} & {$[-0.54]$} & {$[-0.21]$} \\
\hline \multirow[t]{3}{*}{ Economic Freedom } & 0.179 & -0.1682 & -0.291 & \\
\hline & $(0.40)$ & $(-0.30)$ & $(-0.51)$ & \\
\hline & {$[0.39]$} & {$[-0.24]$} & {$[-0.43]$} & \\
\hline \multirow[t]{3}{*}{ Banking Crisis } & 1.3238 & 2.6841 & 2.3936 & 2.3864 \\
\hline & $(2.91)^{*}$ & $(2.52)^{* * *}$ & $(2.25)^{* *}$ & $(2.27)^{* *}$ \\
\hline & {$[1.87]^{*}$} & {$[1.98]^{* *}$} & {$[1.89]^{*}$} & {$[1.95]^{* *}$} \\
\hline McFadden $R^{2}$ & 0.1848 & 0.3055 & 0.2998 & 0.2904 \\
\hline S.E.E. & 0.3865 & 0.3659 & 0.3855 & 0.3844 \\
\hline Like. Ratio test & $14.93^{* *}$ & $21.85^{* * *}$ & $20.17 * * *$ & $19.75^{* * *}$ \\
\hline Hosmer-Lemeshow test & 6 & $14.45^{*}$ & $13.27^{*}$ & 10.18 \\
\hline No. Of Observations & 76 & 60 & 54 & 55 \\
\hline
\end{tabular}

Notes: 1. Figures in parentheses are the z-statistics whereas those in brackets are the z-statistics computed from the GLM robust standard errors.

2. $* * *, * * *$, and + denote respectively statistical significance at the $1 \%, 5 \%, 10 \%$ and $20 \%$ levels. 


\section{KAM HON CHU Theory of Deposit Insurance Adoption}

second column. While both sets of results produce some satisfactory findings like correct signs, statistical significant estimates, high McFadden $R^{2}$, etc., they suffer a couple of defects -namely, the Economic Freedom Index has the wrong sign, though statistically insignificant, and also the model fails to pass the Hosmer-Lemeshow goodness-of-fit test marginally at the $10 \%$ level.

The findings for the Economic Freedom Index (and also the other proxies) can possibly be due to a couple of reasons. First, they can simply arise as a sample property -- a strong positive correlation of 0.48 between the deposits-GDP ratio and the Economic Freedom Index (as well as other proxies). The strong correlation is not surprising as most advanced economies are democratic on the one hand and also have high volume of deposits relative to GDP on the other. This high collinearity probably causes the estimate for the Economic Freedom Index to be statistically insignificant and also to change from the right sign to the wrong sign when the sample size becomes smaller. ${ }^{34}$ Second, as already mentioned, the political-economy process is so complex that it is unlikely to be captured by a scalar index with a simple linear relationship.

Further tests indicate that the Economic Freedom Index can be regarded as a redundant variable whereas the deposits-GDP ratio cannot. We therefore drop the Economic Freedom Index from the specification and the results are reported in the last column of Table 5. As can be seen, the estimates for all the explanatory variables have the correct signs as expected and they are all statistically significant except government ownership of banks. These findings together with the McFadden $R^{2}$, the likelihood ratio test and the Hosmer-Lemeshow goodnessof-fit test reveal that the model offers a satisfactory explanation for EDIS adoption by economies which were not under the external political pressure from EU accession or IMF influence.

Based on this last set of logit results, we compute and report in Table 6 the odds ratios and the marginal effects at the means (MEMs) due to a change in one of the explanatory variables, assuming all other things equal and also no banking crisis initially. ${ }^{35}$ To illustrate, for all the 55 countries in our sample, an increase in the deposits-GDP ratio numerically by 0.1 (or 10 percentage points if deposits are expressed as a percentage of GDP), all other things equal,

\footnotetext{
${ }^{34}$ The deposits-GDP ratio or the Economic Freedom Index (or the other proxies) has the right sign and is statistically significant if either one is included individually in the regression. However, the Economic Freedom Index (or the other proxies) becomes statistically insignificant if both variables are included. As can be seen, in larger samples the Economic Freedom Index (and the other proxies) has the correct sign as predicted, but it changes to the wrong sign in smaller samples.

${ }^{35}$ Unlike in the case of a LPM where the marginal effect of an increase in an explanatory variable is its regression coefficient, i.e. a constant, the marginal effect in the case a logit model is not a constant. Following the convention, we compute the marginal effects by valuing the explanatory variables (except banking crisis) at their sample means.
} 
Table 6: Effects of Change in the Explanatory Variables on EDIS Adoption

\begin{tabular}{|l||c|c|c|c|}
\hline \multicolumn{1}{|c|}{} & & \multicolumn{3}{c|}{ Marginal Effect at the Means } \\
\cline { 3 - 5 } & Odds Ratio & All Countries & $\begin{array}{c}\text { Developed } \\
\text { Countries }\end{array}$ & LDCs \\
\hline \hline No. Of Obs. & & 55 & 20 & 35 \\
\hline Initial Odds & & 1.233 & 6.6659 & 0.4451 \\
\hline Deposits/GDP & 1.5929 & 0.1108 & 0.0444 & 0.1068 \\
\hline Concentration Ratio & 0.4799 & -0.1804 & -0.1077 & -0.132 \\
\hline Government Ownership of Banks & 0.9529 & -0.012 & -0.0056 & -0.0102 \\
\hline Banking Crisis & 10.87 & 0.3784 & 0.1168 & 0.5208 \\
\hline
\end{tabular}

Notes:

1. Odds are defined as the ratio of the probability of EDIS adoption to the probability of no adoption.

2. The odds ratio is the odds after a change in an explanatory variable to the initial odds, assuming all other things equal. An odds ratio larger (smaller) than one implies an increase (a decrease) in the probability of EDIS adoption after the change, and the larger (smaller) the ratio, the larger (smaller) the increase (decrease).

3. The marginal effect is the change in the probability of EDIS adoption due to a change in an explanatory variable with all explanatory variables valued at their sample means except banking crisis, which is assumed to equal to zero (i.e. no banking crisis initially).

4. Since banking crisis is a dummy variable, the marginal effect measures the increase in the probability of EDIS adoption as a result of occurrence of a systemic banking crisis.

leads to an odds ratio of 1.59 (i.e., the ratio of the new odds of 1.96 after the change to the initial odds of 1.23), implying an increase in the probability of EDIS adoption from the initial 0.55 to 0.66 following the change in the deposits-GDP ratio or, in other words, an MEM of 0.11. Table 6 also reports the MEMs for developed countries and LDCs, respectively at 0.044 and 0.107 , suggesting that, at the margin, the impact of the increase in deposits-GDP ratio on EDIS adoption is stronger among the LDCs. These findings are plausible as almost all advanced economies already have high deposits-GDP ratios and EDIS at the same time.

Similarly, the odds ratios suggest that if the concentration ratio (or government ownership of banks) increases by 0.1 , then the probability of EDIS adoption will drop by a considerable 0.18 (or a meager 0.01 ) according to the MEMs. The intuition is straightforward and has already been mentioned by our theory: when the banking industry is more concentrated or monopolized, whether in the hand of the private sector or the government, there is little 


\section{KAM HON CHU Theory of Deposit Insurance Adoption}

incentive for EDIS adoption. The MEMs for the developed countries and LDCs suggest that the impacts are not significantly different between the two groups.

In contrast, the impact of banking crises is more prominent and plausible in practice. The odds ratio suggests that the probability of EDIS adoption would increase significantly by an MEM of 0.38 to 0.93 after an occurrence of a systemic banking crisis. In reality most economies set up EDIS after experiencing systemic banking crises; and the MEM of 0.52 suggests that LDCs are more inclined to do so than the developed countries.

The above findings and interpretations are illustrative rather than definitive. After all, the marginal effect of a change in an explanatory variable in a logit or probit model is not a constant but a function of the explanatory variables. Furthermore, as already mentioned earlier, these findings may not represent the actual response or timing in EDIS adoption due to our crosssectional specification.

Although it is infeasible to estimate a hazard model of EDIS adoption based on the available data, we address the adoption timing or causation problem by carrying out an alternative statistical analysis based on the available data plus data on government ownership of banks in 1995 provided by La Porta et al. (2002). More specifically, we have data on EDIS and the explanatory variables for 1995. Then we classify these countries into three groups: (I) those already had EDIS by 1995, (II) those did not have EDIS in 1995 but set up one in subsequent years, and (III) those still had not yet set up EDIS by 2013, and compare them statistically, in particular the last two groups - i.e., those economies did not have EDIS in 1995. The summary statistics and comparisons are tabulated as Table 7. As can be seen, economies in Group II had, on the average, a higher deposits-GDP ratio, a lower concentration ratio, a lower government ownership of banks and higher economic freedom in 1995 than those economies in Group III. All these characteristics are consistent with the predictions of our theory; and more importantly, they also shed some light on the timing and causation problem - how these economies' attributes as observed in 1995 affected their decisions to adopt EDIS in subsequent years.

Like Demirgüç-Kunt et al. (2008), this study contributes to the literature by providing empirical findings to explain why economies adopt EDIS. Admittedly, our study is technically simple and parsimonious in terms of model specification and it focuses on only a few explanatory variables relevant to our theory. By contrast, theirs is econometrically more sophisticated and, thanks to a larger panel dataset, is able to incorporate more variables to explore and analyze what the determinants of EDIS adoption are but without reference to any specific economic theory. Despite the differences in model specifications, econometric techniques, data used, etc., both studies find that banking crisis, external political pressure from the IMF and EU are common factors affecting EDIS adoption. On the other hand, there are 
Table 7: Comparison of Economies With and Without EDIS in 1995

\begin{tabular}{|l||c|c|c|c|}
\hline & $\begin{array}{c}\text { Group I: } \\
\text { Economies } \\
\text { already had } \\
\text { EDIS in 1995 }\end{array}$ & $\begin{array}{c}\text { Group II: } \\
\text { Economies did } \\
\text { not have EDIS in } \\
1995 \text { but set up } \\
\text { one in subsequent } \\
\text { years }\end{array}$ & $\begin{array}{c}\text { Group III: } \\
\text { Economies } \\
\text { not yet have } \\
\text { EDIS as of } \\
2013\end{array}$ & $\begin{array}{c}\text { Equality } \\
\text { Test of } \\
\text { Means } \\
\text { between } \\
\text { Groups II } \\
\text { and III }\end{array}$ \\
\hline \hline Deposits/GDP & $\begin{array}{c}47.9 \% \\
(41)\end{array}$ & $\begin{array}{c}45.3 \% \\
(27)\end{array}$ & $\begin{array}{c}32.6 \% \\
(28)\end{array}$ & $-1.09+$ \\
\hline Concentration Ratio & $49.4 \%$ & $59.0 \%$ & $78.5 \%$ & $3.04 * * *$ \\
& $(43)$ & $(30)$ & $54.4 \%$ & $1.60^{*}$ \\
\hline Government & $39.0 \%$ & $33.4 \%$ & $(7)$ & $-1.08+$ \\
Ownership of Banks & $(40)$ & 6.3 & 5.8 & $(19)$ \\
\hline Economic Freedom & 6.6 & $(23)$ & & \\
& $(42)$ & \multicolumn{3}{|c|}{} \\
\hline
\end{tabular}

Notes:

1. For deposits/GDP, concentration ratio, government ownership of banks and economic freedom, the reported figures are the average values.

2. Figures in parentheses are the numbers of observations included in the calculations.

3. For the test of equality of means reported in the last column, the figures are the t-statistics based on one-tail tests.

4. ***,**, $*$, and $\dagger$ denote respectively statistical significance at the $1 \%, 5 \%, 10 \%$ and $20 \%$ levels.

some differences in the empirical findings: the deposits-GDP ratio is found to be a significant factor in this study but statistically insignificant in theirs; government ownership of banks carries a negative sign according to our findings but carries an opposite sign in theirs, though statistically insignificant in both cases; and finally we have found the concentration ratio carries a negative sign and is statistically significant, whereas it is not considered at all by them.

In practice, EDIS can be adopted for one reason or another, or a combination of various factors with different weights - some countries adopted EDIS because of banking instability, others yielded to external political pressure, and so on. Simply put, our model is admittedly not one-size-fits-all. Nevertheless, the above econometric results on the average lend support to our bureaucratic-entrepreneurial theory. Given the limitations in the econometric analysis, the next section offers a case study of Canada as a further piece of evidence to support our theory.

\section{A Case Study of Canada}

Canada is one of the advanced democratic economies in the world. Its deposits-GDP ratio stood at 40.2 or the $20^{\text {th }}$ highest in the world in 1967 , the year when CDIC was established. The two 


\section{KAM HON CHU Theory of Deposit Insurance Adoption}

most significant types of financial intermediaries in the deposit market were the larger, safer chartered banks and the relatively smaller and riskier TMLs. The Government did not have any ownership of these depository institutions. This political and economic background is consistent with the conditions discussed earlier according to our theory. Needless to say, the external political pressure from the IMF or EU can entirely be ruled out as a determinant for Canada to adopt EDIS at that time. Nor was systemic banking instability a major factor or threat. The last bank failure took place more than 40 years ago in 1923 when the Home Bank of Canada failed because of a large-scale fraud by its senior management. The stability of the Canadian banking system has long been well recognized: despite the system-wide US bank failures during the Great Depression, the Canadian banking system was immune from any contagion effect and none of its banks failed (see e.g. Friedman and Schwartz 1963). After ruling out these determinants of EDIS adoption, the Canadian case provides virtually a natural laboratory for testing the empirical validity of our theory.

Almost all studies of deposit insurance in Canada maintain that the establishment of CDIC in 1967 was based on the public-interest reasons, such as preventing bank runs and promoting competition. One exception is Carr et al. (1994), who postulate that the establishment of CDIC was politically motivated. Their political hypothesis and our theory are not mutually exclusive. In fact, both studies are based on the private-interest theory and hence there are certain commonalities. More specifically, Carr et al. argue and show empirically that CDIC was introduced to support TMLs by forcing chartered banks to subsidize them through an EDIS which required all chartered banks and TMLs to be members and to pay the same non-riskrated premiums (see Carr et al. 1994, pp. 43-66 for details). In essence, their main theme is the same as some of our aforementioned hypotheses.

The two theories are indeed complementary to each other in offering a more complete political economy explanation for EDIS adoption in Canada. Both theories predict that the establishment of CDIC favored the TMLs. Available historical statistics (Section J, Leacy 1983 ) indicate that chartered banks' holding of deposits from the general public stood at $\$ 31.5$ billion or about 3.2 times the deposits held by TMLs in 1971, whereas the figures were respectively $\$ 13.8$ billion and 4.3 times in 1963 . This casual empiricism reflects a shift of market shares from chartered banks to TMLs after CDIC was set up. Admittedly, this shift of market shares started before 1967 because TMLs expanded their operations as a result of a growing economy, residential construction and real estate development during the 1960s. But had it not been for the establishment of CDIC in 1967, TMLs might not be able to maintain their strong momentum of growth over this period following the financial difficulty of British Mortgage Trust Corporation in 1965 and the run on York Trust and Savings Corporation in 1966. The average annual growth in chartered bank deposits was about $11 \%$ both before and after the establishment of CDIC. By contrast, the average annual growth in TML deposits was 
about $17 \%$ before 1967 and remained robust - at about $14 \%$ - in subsequent years, thanks to CDIC. Carr et al. recognize that the regulatory authority "may serve to provide private benefits for favored groups of institutions and improve the career prospect of financial sector regulation" (1994, p. 95). However, their empirical analysis focuses on testing the two competing hypotheses of EDIS adoption - namely the political hypothesis versus the economic efficiency hypothesis. To test our theory, we focus here on the regulators' gains from the establishment of CDIC.

Table 8 shows some selected statistics for CDIC in its first 25 years of operation.

Table 8: CDIC Statistics for Selected Years, 1967-1992

\begin{tabular}{|l||l|l|l|l|l|}
\hline Year & $\begin{array}{l}\text { Number of } \\
\text { Member } \\
\text { Institutions }\end{array}$ & $\begin{array}{l}\text { Number of } \\
\text { CDIC } \\
\text { Employees }\end{array}$ & $\begin{array}{l}\text { CDIC's } \\
\text { Annual } \\
\text { Budget }(\$ \mathrm{~m})\end{array}$ & $\begin{array}{l}\text { Number of } \\
\text { Employees } \\
\text { per } \\
\text { Member } \\
\text { Institutions }\end{array}$ & $\begin{array}{l}\text { Annual } \\
\text { Budget per } \\
\text { Employee } \\
(\$)\end{array}$ \\
\hline \hline 1967 & 69 & $1^{*}$ & 0.4 & $0.0144^{*}$ & $400,000^{*}$ \\
\hline 1980 & 123 & 5 & 0.8 & 0.0407 & 160,000 \\
\hline 1982 & 186 & 7 & 1 & 0.0376 & 142,857 \\
\hline 1987 & 162 & 45 & 9 & 0.2778 & 200,000 \\
\hline 1992 & 142 & 94 & 29 & 0.662 & 308,511 \\
\hline \multicolumn{7}{|l||}{} & Average Annual Growth Rate (\%) & \\
\hline $1967-92$ & 2.9 & $19.9^{*}$ & 18.7 & $16.5^{*}$ & $-1.0^{*}$ \\
\hline $1980-92$ & 1.2 & 27.7 & 34.9 & 26.2 & 5.6 \\
\hline
\end{tabular}

Source: CDIC Annual Report 1998-1999 and the author's calculations.

Note: * These figures do not reflect the true picture and should be interpreted with care because, according to CDIC, staff was also provided by the Department of Insurance and the Department of Finance; however, the actual number is not disclosed by CDIC. 


\section{KAM HON CHU Theory of Deposit Insurance Adoption}

Apparently, both CDIC's number of employees and annual budget increased dramatically over the years. When CDIC was initially set up, the Federal Government subscribed $\$ 10$ million of capital, higher than the $\$ 6$ million deposit insurance fund raised from member institutions, which paid an annual premium of $1 / 30$ of $1 \%$ of insurable deposits. But the latter easily became the main source of CDIC's funds in subsequent years as insurable deposits grew over time and the premium was raised to $1 / 10$ of $1 \%$ of insurable deposits in 1991. This is consistent with our theory in that EDIS is mainly privately rather than publicly funded. With this funding source, CDIC's annual budget grew dramatically by more than 70 times from a meager $\$ 0.4$ million in 1967 to $\$ 29$ million in 1992, whereas its staff increased from one employee only to 94 employees over the same period. It can be argued that the expansion was due to such factors like increases in member institutions and inflation. But over these 25 years, the number of member institutions roughly doubled and the inflation rate (measured by changes in the consumer price index) was $364 \%$ or about $6 \%$ p.a. Apparently, the growth in CDIC's staff and annual budget was considerably more than the need to accommodate the growth in the deposittaking industry and inflation. This phenomenon reflects government bureaucrats' gains in power, opportunities for promotion and perquisites, etc., from the growth of the bureaucracy and its budget (Niskanen 1971).

In sum, our theory is also empirically supported by the above analysis and findings with reference to Canada's case of EDIS adoption.

\section{Conclusion}

This study follows the private-interest view of regulation and the models a la Peltzman (1976), Becker (1983) and Kane (1989) to develop a bureaucratic-entrepreneurial theory to explain EDIS adoption. In our theory, the regulator, i.e., the provider or administrator of EDIS, plays a dual role as both a bureaucrat (e.g. Niskanen 1971) and an entrepreneur to maximize his own self-interest by building an enterprise - an EDIS in this case.

Comparing our theory with other private-interest theories in the literature, there are probably more similarities than differences because our theory is essentially an extension. Those theories are more general in nature and can be applicable to various industries, whereas our theory focuses on EDIS adoption, although theoretically our economic ideas and analytical framework can be applied to other areas as well - for instance, our theory can potentially be applied to analyze why the European Union has established an ever increasing number of administrative agencies which enjoy independent legal status and have separate budgets since the 1990s. Nevertheless, our theory differs in some aspects and contributes to the literature in that it integrates bureaucratic behavior and private interest together to give the regulator a dual role to play both as a bureaucrat and an entrepreneur (or enterprise builder). As in those privateinterest theories, in our theory interest groups have a role to play in the regulatory process, but 
the regulator plays a more explicit and active role to maximize his own utility. Put differently, the regulator is not simply an agent or a puppet of the interest groups, and he cares about his own interests more than the interest groups'. Thus, a prominent difference between our theory and the capture theory is that the regulator in our theory does not necessarily have to be captured by the regulated.

Besides the theoretical contribution, this study contributes to the empirical literature on EDIS adoption. Several empirically testable hypotheses, or conditions under which EDIS adoption is more likely follow or can be inferred from our theory. To some extent, they are supported by the statistics, stylized facts, as well as the formal regression results of binarychoice models based on cross-country data for 86 economies in 2013. To recapitulate, our empirical findings indicate that: most EDIS are (i) publicly administered and (ii) privately funded; (iii) all EDIS have compulsory membership; (iv) most EDIS have non-risk rated insurance premiums, particularly when they were initially set up; on the other hand, economies with EDIS have on the average (v) larger deposit markets, (vi) lower concentration ratios in their banking industries, (vii) lower government ownership of banks, and (viii) higher levels of economic freedom. In addition to the formal statistical and regression analyses, we examine Canada's experience in introducing deposit insurance in 1967 as a case study. Overall, all the empirical findings lend support to our theory.

Our empirical findings also indicate clearly that experience of systemic banking crisis is a significant determinant of EDIS adoption. The regression results suggest that external political pressure from EU accession, the IMF and the World Bank, emulation of other countries, and so on, are also important factors, as found earlier by Demirgüç-Kunt and Detragiache (2002) and Demirgüç-Kunt et al. (2008). Admittedly, these determinants have certainly been taken into consideration by regulators of some economies in their decisions to adopt EDIS. However, it should be stressed that these factors and our theory are not mutually exclusive. Following a banking crisis, for example, a regulator may take the opportunity to decide to set up an EDIS so as to convince the general public that he has taken steps to implement a policy to maintain banking stability on the one hand, and to maximize his own self-interest on the other. In this case, the two motives are not mutually exclusive. How to disentangle them will be left for future research.

Deposit insurance is part of the financial safety net. Kane (2009) has offered two reasons why safety nets expand over time: (i) large financial institutions whose operations lie formally outside the safety net have strong incentives to make themselves too difficult for regulators to let them fail and unwind in crisis circumstances, and (ii) safety-net managers under-invest in crisis planning during good times and consequently crisis-generated changes in the ordering of regulatory norms dispose regulators to rescue financial institutions that are difficult to fail and unwind without holding themselves closely accountable for either the costs or the distributional 


\section{KAM HON CHU Theory of Deposit Insurance Adoption}

effects of the subsidies the rescue engenders. Though simply, our theory can also be applied to explain why safety nets, such as EDIS, expand over time because of deposit insurance providers' bureaucratic-entrepreneurial behavior, as evidenced by the growth of CDIC's annual budget over the years under study.

Before we come to a close, perhaps it should be emphasized that this study is purely a positive analysis, although the term bureaucracy often carries a derogatory connotation in our daily use. It is one thing that EDIS are set up because of regulators' bureaucratic behavior. But it is a different thing whether EDIS can be effectively administered to maintain banking stability. All in all, this paper not only offers an economic theory to explain EDIS adoption but also potentially sheds new light on other areas of financial regulation.

\section{References}

Acheson, Keith, and John Chant (1972) "The Choice of Monetary Instruments and the Theory of Bureaucracy.” Public Choice 12: 13-33.

(1973) "Bureaucratic Theory and the Choice of Central Bank Goals: The Case of the Bank of Canada." Journal of Money, Credit and Banking 5: 637-55.

Angrist, Joshua D., and Jorn-Steffen Pischke (2009) Mostly Harmless Econometrics: An Empiricist's Companion. Princeton: Princeton University Press.

Baltensperger, Ernst, and Jean Dermine (1990) "European Banking: Prudential and Regulatory Issues," pp. 17-36 in J. Dermine (ed.) European Banking in the 1990s, Oxford: Basil Blackwell.

Barth, James R. (1991) The Great Savings and Loan Debacle. Washington, D.C.: American Enterprise Institute.

Barth, James R., Dan R. Brumbaugh, and Robert E. Litan (1992) Bank Failures are Sinking the FDIC." Challenge March/April: 4-15.

Barth, James R., Gerard Caprio Jr. and Ross Levine (2006) Rethinking Bank Regulation: Till Angels Govern. Cambridge: Cambridge University Press.

(2013) "Bank Regulation and Supervision in 180 Countries from 1999 to 2011." World Bank Surveys on Bank Regulation. Washington, D.C.: World Bank.

Becker, Gary (1983) "A Theory of Competition among Pressure Groups for Political Influence.” Quarterly Journal of Economics 98: 371-400.

Benston, George, and George Kaufman (1988) "Regulating Bank Safety and Performance" as Chapter 3, pp. 63-99, in William Haraf and Rose Kushmeider (eds.) Restructuring Banking and Financial Services in America. Washington, D.C.: American Enterprise Institute.

Boot, Arnound, and Anjan Thakor (1993) "Self-Interested Bank Regulation." American Economic Review 83: 206-12. 
Calomiris, Charles, and Stephen Haber (2014) Fragile by Design: The Political Origins of Banking Crises and Scarce Credit. Princeton: Princeton University Press.

Calomiris, Charles, and Matthew Jaremski (2016) "Deposit Insurance: Theories and Facts." Annual Review of Financial Economics 8: 97-120.

Calomiris, Charles, and Eugene White (1994) “The Origins of Federal Deposit Insurance," pp. 145-88 in C. Goldin and G.D. Libecap (eds.) The Regulated Economy: A Historical Approach to Political Economy. Chicago: Chicago University Press.

Canadian Deposit Insurance Corporation (1999) Annual Report 1998-1999. Toronto: Canadian Deposit Insurance Corporation.

Carr, Jack L., Frank Mathewson and N.C. Quigley (1994) Ensuring Failure: Financial System Stability and Deposit Insurance in Canada. Toronto: C.D. Howe Institute.

(1995) "Stability in the Absence of Deposit Insurance: the Canadian Banking System 1890-1966." Journal of Money, Credit and Banking 27: 1137- 58.

Chan, Y.S., S.I. Greenbaum, and A.V. Thakor (1992) "Is Fairly Priced Deposit Insurance Possible?" Journal of Finance 47: 227-45.

Chatov, R. (1978) "Government Regulation: Process and Substantive Impacts," pp. 223-54, in Kerr, M., and L.E. Preston (eds.) Research in Corporate Social Performance and Policy Volume 1, JAI Press.

Che, Yeon-Koo (1995) "Revolving Doors and the Optimal Tolerance for Agency Collusion." RAND Journal of Economics 26: 378-97.

Chu, Kam Hon (2000) "Saving Bonds as Deposit Insurance." HKCER Letters No. 62: 6-8. (2003) "Deposit Insurance and Banking Crises in the Short and Long Run." Cato Journal 23: 265-80.

(2011) "Deposit Insurance and Banking Stability." Cato Journal 31: 99-117.

Cowen, Tyler, and Randall Kroszner (1990) "Mutual Fund Banking: A Market Approach." Cato Journal 10: 223-37.

Demirgüç-Kunt, Asli, and E. Detragiache (2002) "Does Deposit Insurance Increase Banking System Stability? An Empirical Investigation." Journal of Monetary Economics 49: 13731406.

Demirgüç-Kunt, Asli, and Edward Kane (2002) "Deposit Insurance Around the Globe: Where Does It Work?" Journal of Economic Perspective 16: 175-95.

Demirgüç-Kunt, Asli, Edward Kane, and Luc Laeven (2008) "Determinants of Deposit Insurance and Design." Journal of Financial Intermediation 17: 407-38.

(2014) “Deposit Insurance Database." IMF Working Paper WP 14/118.

(2015) "Deposit Insurance around the World: A Comprehensive Analysis and Database.” Journal of Financial Stability 20: 155-83. 
Demirgüç-Kunt, Asli, Baybars Karacaovali and Luc Laeven (2005) "Deposit Insurance around the World: A Comprehensive Database." The World Bank, Policy Research Working Paper Series: 3628. Washington, D.C.: World Bank.

Diamond, Douglas, and Philip Dybvig (1983) "Bank Runs, Deposit Insurance, and Liquidity." Journal of Political Economy 91: 401-19.

Economides, Nicholas, Glenn Hubbard and Darius Palia (1996) "The Political Economy of Branching Restriction and Deposit Insurance: A Model of Monopolistic Competition among Small and Large Banks." Journal of Law and Economics 39: 667-704.

(1999) "Federal Deposit Insurance: Economic Efficiency or Politics?" Regulation 22(3): 15-7.

Economist Intelligence Unit (2011) Democracy Index 2011: Democracy Under Stress. London: EIU.

Engineer, Merwan, Paul Schure, and Mark Gillis (2013) "A Positive Analysis of Deposit Insurance Provision: Regulatory Competition among European Union Countries.” Journal of Financial Stability 9: 530-44.

Fraser Institute (2012) Economic Freedom of the World: 2012 Annual Report. Vancouver, B.C.: Fraser Institute.

Freedom House (2016) Freedom in the World. Washington, D.C.: Freedom House.

Freixas, X., and J.C. Rochet (1998) "Fairly Priced Deposit Insurance: Is it Possible? Yes. Is it Desirable? No." Research in Economics 52: 217-32.

Friedman, Milton, and Anna Schwartz (1963) A Monetary History of the United States, 18671960. Princeton: Princeton University Press. (1986) Has Government any Role in Money? Journal of Monetary Economics 17: 37-62.

Garcia, Gillian (1999) "Deposit Insurance: Actual and Best Practices." IMF Working Paper 99/54. Washington, D.C.: International Monetary Fund.

Goldberger, Arthur (1964) Econometric Theory. New York: Wiley \& Sons.

Gorton, Gary, and Donald Millineaux (1987) "The Joint Production of Confidence: Endogenous Regulation and $19^{\text {th }}$ Century Commercial Bank Clearing Houses." Journal of Money, Credit and Banking 19: 458-68.

Greene, William H. (2011) Econometric Analysis, $7^{\text {th }}$ edition. Prentice-Hall, New Jersey.

Grossman, Gene, M., and Elhanan Helpman (2001) Special Interest Politics. Cambridge: MIT Press.

Hettich, Walter, and Stanley Winer (1988) "Economic and Political Foundations of Tax Structure." American Economic Review 78: 701-12. 
Huizinga, Harry (2008) “The EU Deposit Insurance Directive: Does One Size Fit All?” pp. 253-79 in Demirgüç-Kunt, Asli, Edward Kane and Luc Laeven (eds.) Deposit Insurance Around the World: Issues of Design and Implementation, MIT Press.

Kahn, Alfred (1989) The Economics of Regulation: Principles and Institutions. Cambridge: MIT Press. Originally published in two volumes in 1970 and 1971 by John Wiley \& Sons.

Kane, Edward (1989) The S\&L Insurance Mess: How Did it Happen? Washington, D.C.: The Urban Institute.

(1990) "Principal Agent Problems in S\&L Salvage." Journal of Finance 45:

$755-64$.

6020.

(1997) "Ethical Foundations of Financial Regulation." NBER Working Paper

(2009) “Financial Safety Nets: Why Do They Keep Expanding?" pp. 1-43 in A. Chen (ed.) Research in Finance. Bingley: Emerald, JAI Press.

Kane, Edward, and Berry Wilson (1998) "A Contracting-Theory Interpretation of the Origin of Federal Deposit Insurance.” Journal of Money, Credit and Banking 30: 573-95.

Kaufman, George G. (1994) "Bank Contagion: A Review of the Theory and Evidence.” Journal of Financial Services Research 8: 123-50.

(1996) "Bank Failures, Systemic Risk, and Bank Regulation." Cato Journal 16(1): 17-45.

Kroszner, Randall, and William Melick (2008) "Lessons from the U.S. Experience with Deposit Insurance.” pp. 181-217 in Demirgüç-Kunt, Asli, Edward Kane, and Luc Laeven (eds.) Deposit Insurance around the World: Issues of Design and Implementation. Cambridge: MIT Press.

Kroszner, Randall, and Philip Strahan (1999) "What Drives Regulation? Economics and Politics of the Relaxation of Bank Branch Restrictions." Quarterly Journal of Economics 114: 1437-67.

(2001) "Obstacle to Optimal Policy: The Interplay of Politics and Economics in Shaping Bank Supervision and Regulation Reforms," pp. 233-66 in F. Mishkin (ed.) Prudential Supervision: What Works and What Doesn't. Chicago University Press.

Kroszner, Randall, and Thomas Stratmann (1998) "Interest Group Competition and the Organization of Congress: Theory and Evidence from Financial Services' Political Action Committee." American Economic Review 88: 1163-87.

Krueger, Anne (1974) "The Political Economy of a Rent-Seeking Society." American Economic Review 64: 291-303.

La Porta, Rafael, Florencio Lopez-de Silanes, and Andrei Shleifer (2002) "Government Ownership of Commercial Banks." Journal of Finance 57: 265-301. 
Laeven, Luc (2002) "Bank Risk and Deposit Insurance." World Bank Economic Review 16: 109-37.

(2004) "The Political Economy of Deposit Insurance." Journal of Financial Services Research 26: 201-24.

Laeven, Luc, Baybars Karacaovali, and Asli Demirgüç-Kunt (2005) "Deposit Insurance Around the World: A Comprehensive Database." World Bank Policy Research Working Paper No. 3628. Washington, D.C.: World Bank.

Leacy, F.H. (1983) Historical Statistics of Canada, $2^{\text {nd }}$ edition. Ottawa: Statistics Canada.

Mackie, J.L. (1965) “Causes and Conditions.” American Philosophical Quarterly 2: 245-64.

McChesney, F.S. (1987) "Rent Extraction and Rent Creation in the Theory of Economic Regulation." Journal of Legal Studies 16: 101-18.

Niskanen, William (1971) Bureaucracy and Representative Government. Chicago: Aldine.

Olson, Mancur (1965) The Logic of Collective Action: Public Goods and the Theory of Groups. Cambridge: Harvard University Press.

Peltzman, Sam (1976) “Towards a More General Theory of Regulation.” Journal of Law and Economics 19: 211-40.

Posner, Richard (1974) "Theories of Economic Regulation." Bell Journal of Economics and Management 5: 335-58.

(1975) "The Social Cost of Monopoly and Regulation." Journal of Political Economy 83: 807-27.

Roe, M.J. (1990) "Political and Legal Restraints on Ownership and Control of Public Companies." Journal of Financial Economics 27: 7-41.

Shleifer, Andrei, and Robert Vishny (1998) The Grabbing Hand: Government Pathologies and Their Cures. Cambridge: Harvard University Press.

Stigler, George (1971) "The Theory of Economic Regulation." Bell Journal of Economics and Management Science 2: 3-21.

Tullock, Gordon (1967) “The Welfare Costs of Tariffs, Monopolies, and Theft." Western Economic Journal 5: 224-32.

Tullock, Gordon, and Richard B. McKenzie (1985) "Bureaucratic Entrepreneurs," as Chapter 11, pp. 171-88 in their The New World of Economics. Homewood: Irwin.

Vidal, Jordi I Banes, Mirko Draka, and Christian Fons-Rosen (2012) "Revolving Door Lobbyists." American Economic Review 102: 3731-48.

Viscusi, W. Kip, Joseph E. Harrington Jr., and John M. Vernon (2005) Economics of Regulation and Antitrust, $4^{\text {th }}$ edition. Cambridge: MIT Press.

World Bank (2001) Finance for Growth: Policy Choices in a Volatile World, Washington, D.C.: World Bank.

World Bank. Global Financial Development Database. Washington, D.C.: World Bank. 